BNWL - 1194

UC -41 , Hea 1 th

and Safety

\title{
A PRELIMINARY SAFETY ANALYSIS OF NEAR SURFACE STORAGE OF RADIOACTIVE WASTE AS SALT CAKES
}

C. M. Unruh

Environmental and Life Sciences Division

\footnotetext{
January 1970
}

RRST WWRESTRIGTED

FEB ${ }^{170}$

BATTELLE MEMORIAL INSTITUTE

PACIFIC NORTHWEST LABORATORIES

RICHLAND, WASHINGTON 99352 
BNWL - 1194

Printed in the United States of America Available from

Clearinghouse for Federal Scientific and Technical Information National Bureau of Standards, U.S. Department of Commerce Springfield, Virginia 22151

Price: Printed Copy $\$ 3.00$; Microfiche $\$ 0.65$ 
BNWL -1194

\author{
A PRELIMINARY SAFETY ANALYSIS OF NEAR SURFACE STORAGE \\ OF RADIOACTIVE WASTE AS SALT CAKES \\ C. M. Unruh
}

\begin{abstract}
A detailed and critical examination of conceivable hazards of the In-Tank-Solidification (ITS) waste storage concept reveals no evidence to indicate that the concept is unsound. No natural hazards leading to the development of unsafe conditions were discovered. Anticipated uses of the nearby land will not jeopardize the multicentury isolation of the waste stored by the ITS concept. Radiological safety considerations indicate the ITS storage concept to be safe and to offer improved long-term waste storage compared to the present liquid storage methods.
\end{abstract}




\section{CONTENTS}

\section{INTRODUCT ION}

SUMMARY

Tank Integrity and Radiolytic Gases . . . $\quad$. $\quad$. 4

Maximum Salt Cake Temperature $\quad$. $\quad . \quad$. $\quad . \quad$. 5

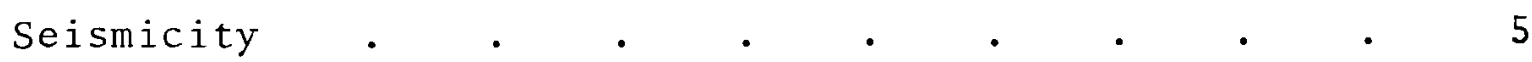

Columbia River Damming . . . . . . . . . . . 6

Irrigaticn . • . . . . . . . . . . 6

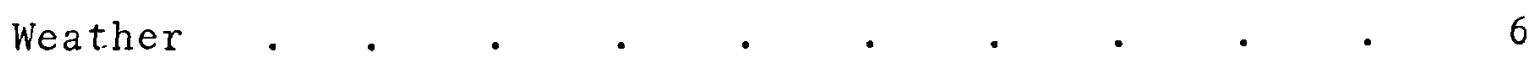

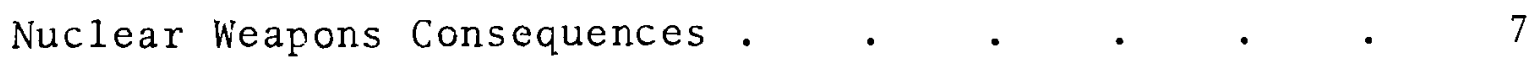

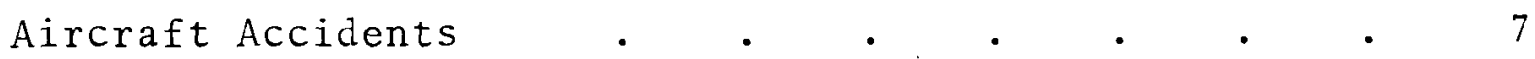

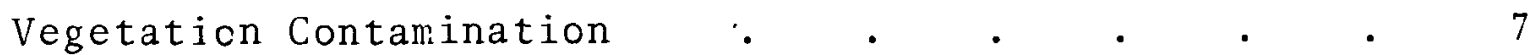

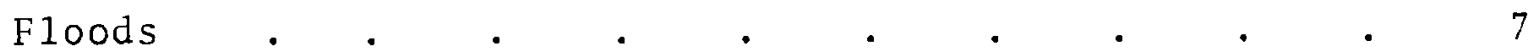

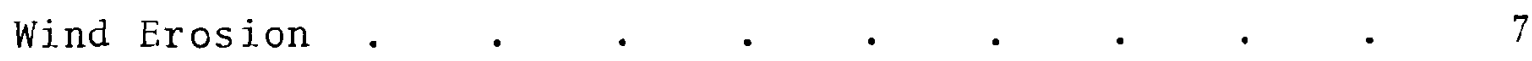

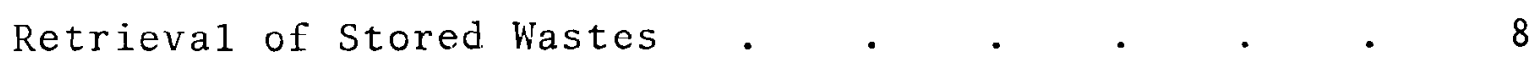

CONCLUSIONS

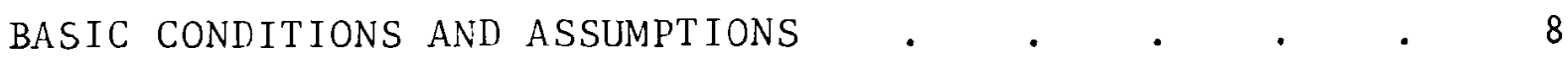

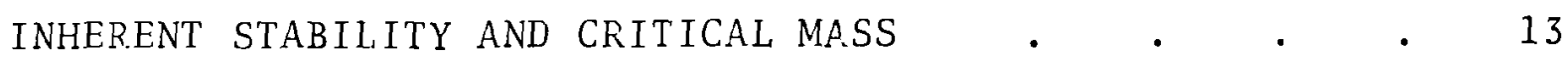

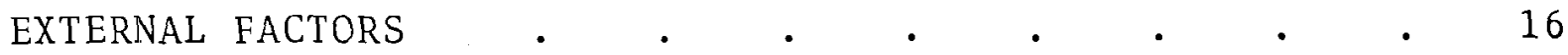

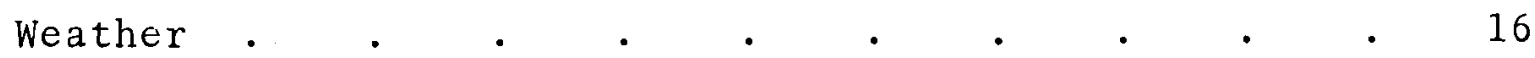

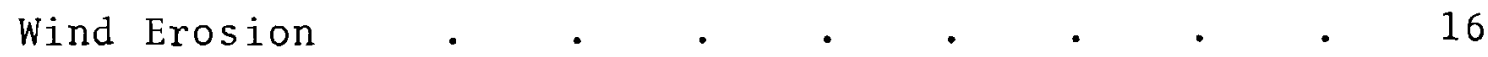

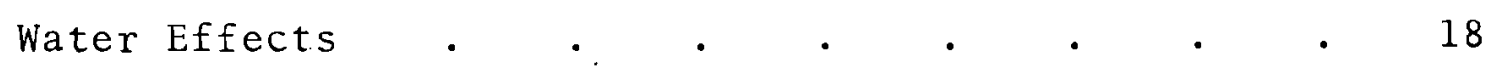

Flash Flooás . . . . . . . . . . . . . 23

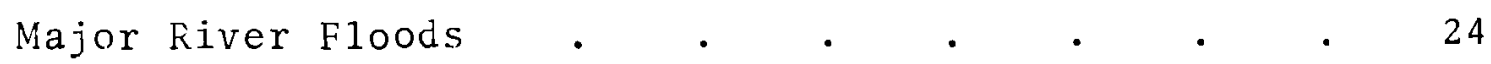

Earth Stability . . . . . . . . . . . . 26

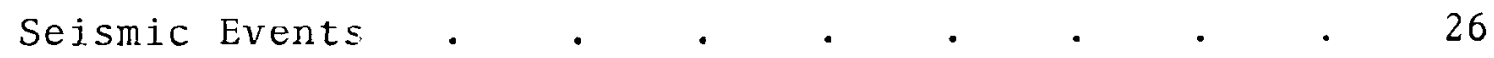

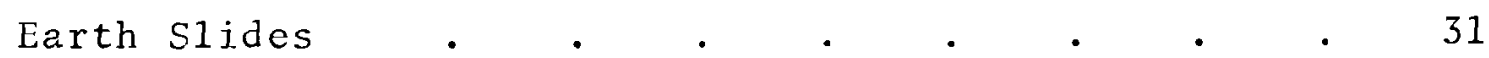

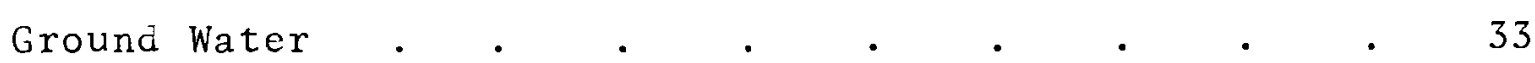

Ben Franklin Dam . . . . . . . . . . . . 33

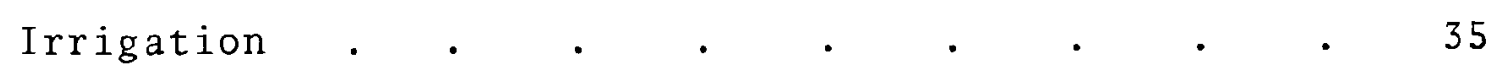

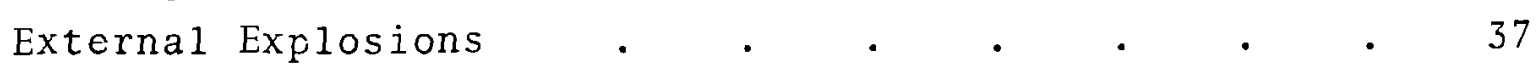

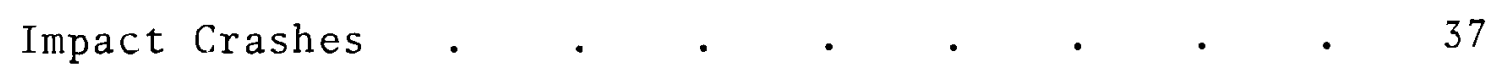

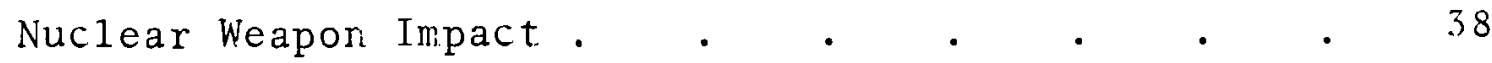


BNWL - 1194

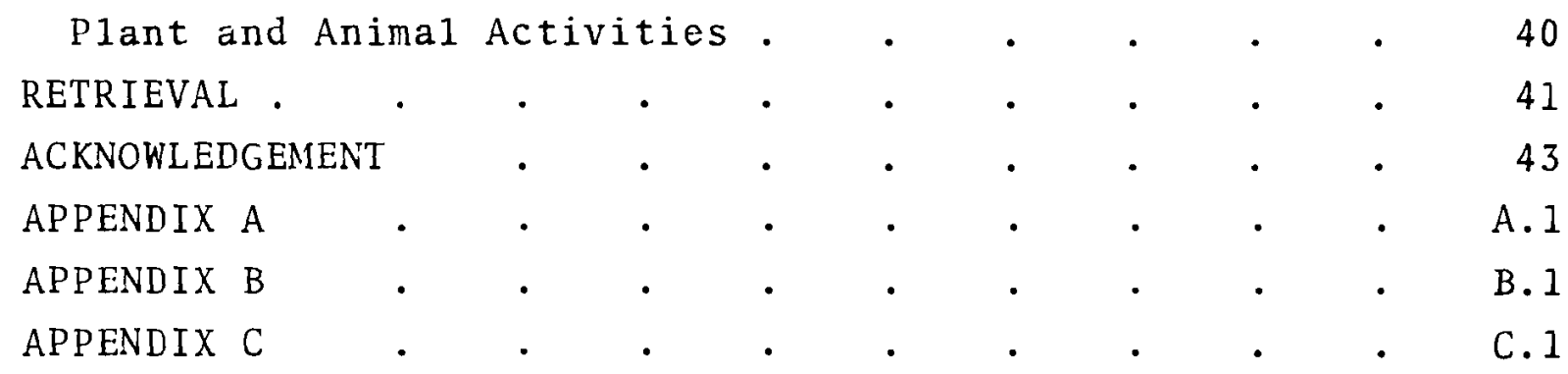




\section{LIST OF TABLES}

1 Radionuclide Contents of a Salt Cake in a Single Tank

2 Maximum Radionuclide Inventory of a Major Tank Farm

3 Anticipated Niaximum Extent of Control Action Required from a 3 MT Weapon

A-1 Radionliclide Concentrations

A-2 Radionuclides Dispersed

A. 2

A-3 Radionuclide Release Rate

A. 3

A-4 Ground level Air Concentrations

A. 3

A-5 Radionuclide Deposition by Inhalation (at $\sim 10$ miles)

A- 6 Ground Deposition Activity Levels

A-7 Activity Leve1 and Corresponding Action

A. 5

A-8 Distance Requiring Controlled Use of Land

A. 6

A-9 External Exposure Rate from Airborne Cloud of ${ }^{137} \mathrm{Cs}$ A.7

A-10 Exposure Rate from Ground Deposited ${ }^{137} \mathrm{Cs} \quad$ A.7

B-1 Radionuclide Inventory in Curies for Early Fallout B.1

B-2 Assumed Activity Level and Corresponding Fossible Actions Under War Time Conditions

B. 3

B-3 ${ }^{137}$ Cs Control Action Contours, $300 \mathrm{kT}$ Weapon B.3

B-4 ${ }^{90} \mathrm{Sr}$ Control Action Contours, $300 \mathrm{kT}$ Weapon B.4

B-5 ${ }^{137}$ Cs Control Action Contours, 3 MT Weapon B. 5

B-6 ${ }^{90}$ Sr Control Action Contours, 3 MT Weapon B.5

B-7 Dose Rate-Time Relationships B.7 


\author{
A PRELIMINARY SAFETY ANALYSIS \\ OF NEAR SURFACE STORAGE \\ OF RADIOACTIVE WASTE \\ AS SALT CAKE \\ C. M. Unruh
}

INTRODUCIION

The In-Tank-Solidification (ITS) Program was developed as a method to increase the safety of storage of radioactive wastes by immobilizing the radioactive fission products. It provides for long-term storage (many centuries) of Hanford radioactive waste with safety and a minimum of attention.

Since the start of radiochemical processing at Hanford in 1944, the high level radioactive wastes have been accumulated and stored as alkaline slurries in underground steellined concrete tanks near the chemical processing plants. The wastes are principally concentrated solutions of sodium nitrate and sodium nitrite, although a host of other salts are present in lesser quantities. When the wastes were made alkaline for storage, some of the insoluble salts and hydrous metal oxides precipitated and settled to the bottom of the tanks as a kind of mud or sludge.

Of principal concern is the safe confinement of the fission products and transuranic elements formed in the nuclear reactors. Some of the radionuclides are chemically identical or similar to elements that have key roles in life processes. For example, cesium, like sodium, will be distributed in many body tissues, while strontium, like calcium, will be concentrated in bones. The addition or the substitution of radioactive materials could damage life forms through exposure to ionizing radiation. The fission products of principal concern, ${ }^{137} \mathrm{Cs}$ and ${ }^{90} \mathrm{Sr}$, have half-lives of about 30 years and 
require controlled storage for a period of several centuries. The transuranic elements have half-lives ranging up to thousands of years and require controlled storage for hundreds of centuries. It is therefore essential that these stored radioactive wastes be isolated from the biosphere over a long time span. Since the steel-lined concrete tanks have a finite life (perhaps an average life of 20 to 40 years) and the radiochemical liquid wastes are mobile, it would be prudent to reduce their mobility. Therefore, the ITS program is currently in operation to evaporate enough water from the wastes to cause the contaminated salts to form massive radionuclideladen salt cakes in existing underground tanks.

About three-quarters of the contaminated wastes can be evaporated directly to form salt cakes. The remaining onequarter of the stored wastes contain too high a concentration of fission products to be treated in this manner. The energy liberated by the radioactive decay process causes these "high-heat" wastes to self-boil in the underground tanks for a few years. Only after a century of decay will the rate of energy release by the long-lived fission products be sufficiently low to allow the heat to be dissipated by natural conduction. Most of these high-heat wastes will be fractionized in the B-Plant processing complex to remove 70 to $90 \%$ of the ${ }^{137} \mathrm{Cs}$ and ${ }^{90} \mathrm{Sr}$, the principal heat-generating fission products. The separated ${ }^{137} \mathrm{Cs}$ and ${ }^{90} \mathrm{Sr}$ will be encapsulated and stored in water-cooled basins until final disposition is determined. The residual salt wastes will be evaporated to salt cakes after the short-lived nuclides have decayed sufficiently to permit the generated heat to be dissipated safely. It is anticipated that the (ITS) program will have solidified the backlog of stored liquid wastes and will be on a current basis by the end of 1975. The only liquid wastes in tanks then will be those required by operating logistics and those held to permit the decay of short-lived nuclides. 
BNWL -1194

Within a given tank, the immobilization of the longlived radionuclides into salt cakes is carried out in three phases. In the first phase, water is removed from the salt solution and the crystallized salt is allowed to accumulate. This concentration step is accomplished by evaporating water with steam coils, heated air, or submerged electrical heaters, in addition to heat generated from the decay of the radionuclides. Additional waste solution is pumped into the concentrating system until the crystallized salts occupy essentially all the waste tank volume. It may not be practical to reduce the water content to the desired extent in one operation. Residual liquid may be removed by recycling supernatant solutions to the evaporator, by blowing air across the surface of the liquid waste in the tank, or by adding a material to sorb the water. Current inventories of precipitated salts and settled sludges (hydrous metal oxides) will not normally be routed through the evaporation step. They will remain, instead, where they first settled unless sufficient long-lived isotopes are present to preclude safe heat dissipation through the soil. These first phase operations are characterized by operator surveillance and process control.

In the second phase, the concentrated wastes are allowed to cool over a period of a few years. During this period, a planned program of observation and analysis is administered. Based on the data obtained, projections are made as to temperature profiles and rates of radiolytic gas formation (if any) for each tank as a function of time. When enough data are obtained to project future conditions with confidence, the tank dome is to be filled with sand (or possibly with grout), the tank is to be disconnected from all operating systems and the surface, and the ground surface is to be stabilized against encroachment by the elements. This second phase is characterized by regular observation and engineering analysis. 
The third phase is one of long-term storage with only occasional surveillance. While life forms should continue to be excluded from contact with the waste, the system is inherently stable and should require only minimal care to maintain safe conditions. If compatible with national criteria, yet to be defined, it appears that the solidified wastes may be left in this state indefinitely.

This document summarizes the preliminary analyses and assessments of the potential hazards associated with the third phase of the In-Tank-Solidification concept--1ong-term storage. The potential hazards of preparing the wastes for long-term storage are discussed elsewhere. (1-4)

\section{SUMMARY}

In-Tank-Solidification, as part of the waste management program, provides a method to store radioactive waste in a stable condition with essentially no interactions with its environment. The waste will not be transported to the atmosphere nor to the ground water under foreseeable environmental conditions. Even catastrophic flooding or dramatic changes of climate such as doubling or tripling the annual maximum rate of rainfall would not create a condition likely to disperse the stored waste.

\section{TANK INTEGRITY AND RADIOLYTIC GASES}

The integrity of the solid salt cake to remain intact and fixed within the soil is not significantly altered by the inevitable deterioration of the steel liners and concrete of the underground tanks. Filling of the tank dome with sand or similar material will leave no large open spaces for the accumulation of explosive, poisonous, or other radiolytic decomposition gases. Filling of the tank dome will also provide structura 1 integrity to assure against a future tank dome collapse. The potential for radiolytic reactions generating 
hazardous quantities of explosive gases appears small but will be evaluated prior to filling the waste tank dome with sand or similar materials.

MAXIMUM SALT CAKE TEMPERATURE

The maximum temperature of the resultant salt cake will be limited to about $260^{\circ} \mathrm{C}$ by controlling the radionuclide content of the drying liquid waste. A waste sample from each tank will be cycled through this temperature to assure that no exothermic reactions occur.

\section{SEISMICITY}

Hanford is considered to be in a region of moderate seismicity, verging on minor seismicity. The geology of the Hanford Project is characterized by a thickness of tertiary basaltic volcanic rocks, upon which rest locally thick sections of tertiary and quaternary sedimentary strata. The sediments resting directly upon the basalt are primarily the Ringold and glaciofluviatile sediments which form the major foundation materials on the Hanford Project. No adverse seismic effects are anticipated in the glaciofluviatile deposits at Hanford. Earthquake ground motion having spectral characteristics similar to recorded California ground motions on firm alluvium can be expected at Hanford. Earthquakes occurring in California have shown no amplification of ground motion.

The Hanford Reservation Area has not been subjected to more than weak ground shaking during historical times which corroborates the estimates that Hanford is in a region of moderate seismicity, verging on minor seismicity. Hanford shows smaller response to distant shocks of destructive magnitude than do surrounding areas. An intensity of MM-VI (Modified Mercalli Scale) has been recommended for use as a sound working value for engineering design purposes, although the extremely 
remote possibility of an earthquake of MM-VII is recognized. An earthquake of MM-VII at any locale on the Project area would produce an acceleration of approximately $0.07 \mathrm{~g}$, not of sufficient magnitude to alter the ground surface. An earthquake of intensity VIII to IX, sufficient to shear the ground surface, is not predicted as likely on the basis of geological evidence of the last 10,000 years.

\section{COLUMBIA RIVER DAMMING}

The Columbia River has been dammed and diverted by such natural occurrences as earth slides, but the effects were strictly local, temporary and did not affect the 200 Area Plateau. The construction and the filling of the pool behind the proposed Ben Franklin Dam would raise the water table, alter ground water flow patterns and rates, and probably would lead to minor landslides along the current river banks. This analysis indicates that none of these phenomena would create an untenable condition with respect to the In-TankSolidification waste management concept.

\section{IRRIGATION}

General quantitative statements cannot be made with reference to the detrimental or beneficial effects of irrigating any specific area in the region of the 200 Area Plateau without detailed simulation modelling. For example, irrigation using ground water from wells to the west of the Project may beneficially lower the water table at the separation plants. Qualitatively, irrigation that would cause ground water from the 200 Area Plateau to enter permeable flow channels should be avoided.

\section{WEATHER}

Recorded weather observations and geologic and hydrologic studies have disclosed no evidence of extreme weather 
conditions during the last 10,000 years posing a significant threat to the adequacy of the In-Tank-Solidification waste storage concept.

NUCLEAR WEAPONS CONSEQUENCES

In the extremely low probability event of a direct tank farm hit by a nuclear weapon, the contents of the entire tank farm could be dispersed. For a 3 megaton (MT) weapon, a crater measuring $1500 \mathrm{ft}$ in diameter and $400 \mathrm{ft}$ in depth could be created. The dispersed ${ }^{90} \mathrm{Sr}$ from the stored waste could require control of crops over a downwind distance of about 300 miles and over a total area of about 20,000 square miles.

\section{AIRCRAFT ACCIDENTS}

The maximum probability of a direct penetrating crash of a jet aircraft into a tank farm area was calculated to be less than $3 \times 10^{-6}$ per year. Such an event could result in local surface contamination. Required corrective actions would be of small magnitude.

VEGETATION CONTAMINATION

Perennial plant root systems could reach the nitrogen rich nutrient layers that may be present around the salt cakes. The growth of perennials directly over the buried waste should be prevented. Burrowing animals will not be found at the salt cake depth.

FLOODS

Flash floods have not occurred at the waste storage areas and the local topography makes such an event unlikely. Major floods would not reach nor affect the 200 Area Plateau.

\section{WIND EROSION}

Gradual wind erosion of the overburden, although highly unlikely, was determined to be the external influence most 
likely to expose and to disperse a part of the salt cake radionuclide inventory. The consequences of wind erosion uncovering the top of an exposed salt cake could require evacuation of people within a 3-mile downwind distance and confiscation of crops for several years within a 20 -mile downwind distance. An overburden protection and periodic inspection can further reduce the unlikely wind erosion dispersal of the radionuclide inventory of a salt cake.

RETRIEVAL OF STORED WASTES

It is possible that development of either environmental or sociological conditions in the future might require movement of the contaminated salts to another location. Since the tanks can be assumed to have lost their liquid containment capability by that time, any retrieval and transport program would be based primarily on the handling of contaminated solids. There are no insurmountable problems in mining and packaging these contaminated solids using currently available technology.

\section{CONCLUSIONS}

A detailed and critical examination of conceivable hazards of the In-Tank-Solidification waste storage concept reveals no evidence to indicate that the concept is unsound. No natural hazards leading to the development of unsafe conditions were discovered. Anticipated uses of the nearby land will not jeopardize the multicentury isolation of the waste stored by the ITS concept. Radiological safety considerations indicate the ITS storage concept to be safe and to offer improved long-term waste storage compared to the present liquid storage methods.

\section{BASIC CONDITIONS AND ASSUMPTIONS}

The tank farms are located on the 200 Area Plateau (Figure 1). The typical geological features of this plateau are used to assess the potential hazards. 
BNWL- 1194

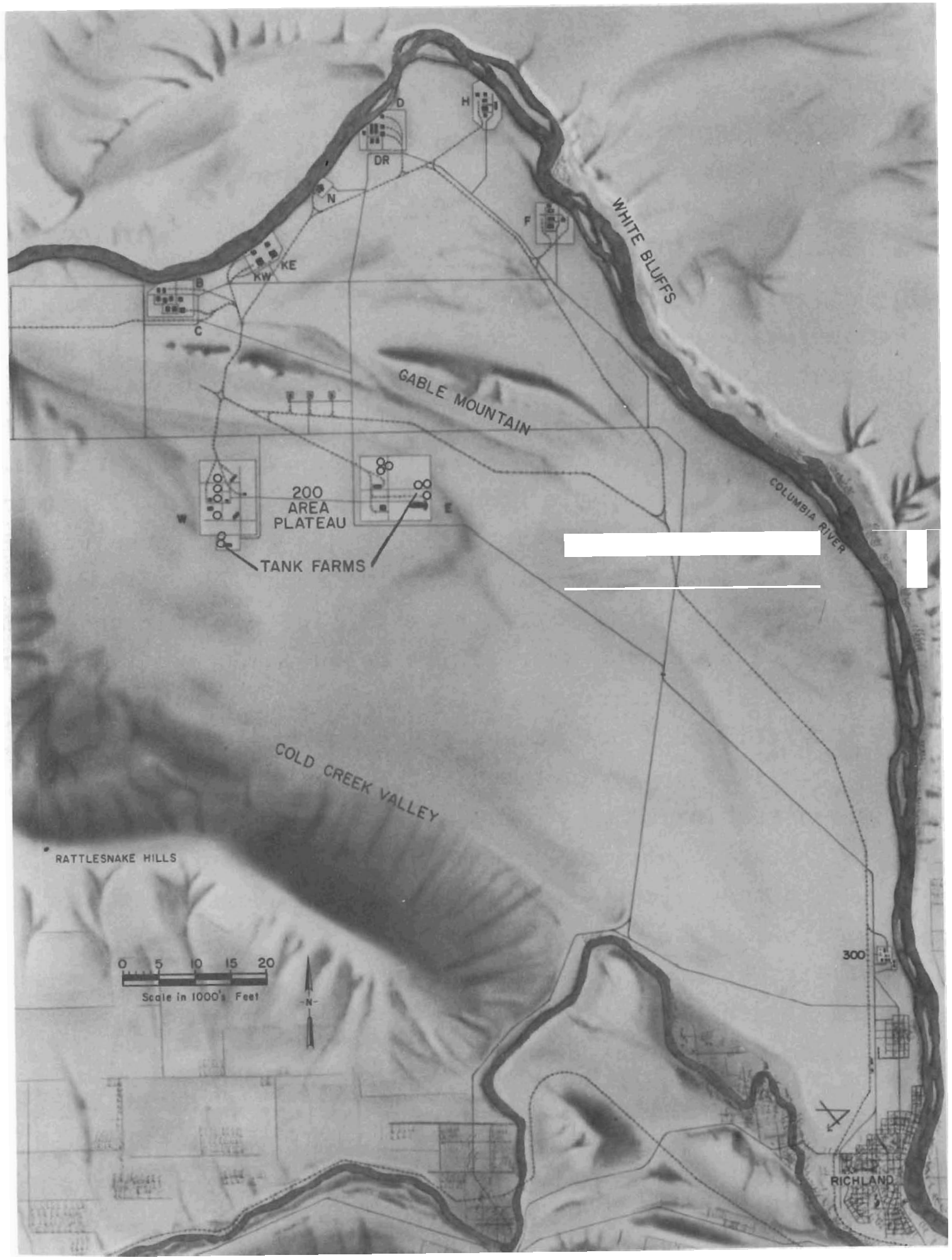

FIGURE 1. Map of Hanford Area 
BNWL- 1194

For this analysis, the following specific conditions are assumed to describe a typical waste storage tank and tank farm prepared for long-term storage.

- Tank BY-101 is taken as typical in size, design, and all other physical properties of the tanks to be considered. The typical waste tank construction is shown in Figure 2.

- Typical salt cakes are composed of the sodium salts of nitrate, nitrite, and aluminate anions in a sodium hydroxide composite. Some carbonates, sulphates, phosphates, and possibly some complexed cyanides will also be present in minor amounts. Small amounts of silicates and chlorides are also present. (4) The specific gravity of the salt cake ranges from 1.5 to 2.0 . A tank filled to a typical load capacity will contain a salt cake weighing in excess of 4000 tons, measuring about 75 ft in diam. eter, and about $20 \mathrm{ft}$ in height. The top surface of the salt cake wi 1? Lic about $30 \mathrm{ft}$ below grade and a minimum of $150 \mathrm{ft}$ above ground water.

- A surveillance period has shown that concentrations of explosive gases generated within the stored waste will be inconsequential.

- The heat generation within the waste is sufficiently low so that an air space is not required above the waste for heat dissipation purposes.

- The tanks are filled with an inert material such as sand to eliminate the void space that might permit the collapse of the tank dome.

- All tank dome penetrations are filled with sand, grout, or similar materials to avoid a direct air channel to the salt cake.

- The top of the tank farm is covered with a soil stabilizing cap of rocks, sand, or clay extending over the tank farm area to provide protection against wind and water erosion. 
BNWL - 1194

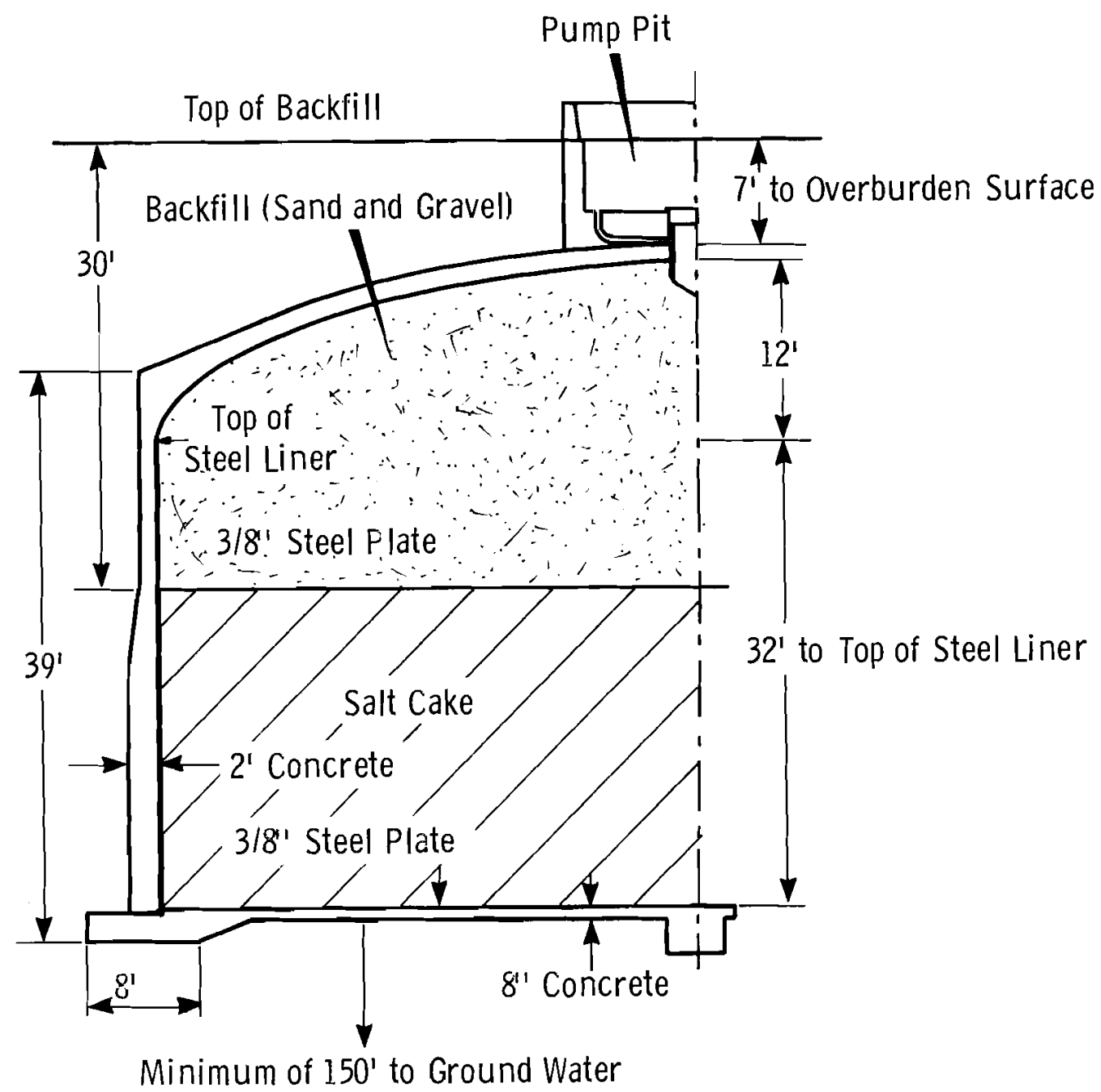

FIGURE 2. Typical Waste Storage Tank Construction 
- There are no pipes connecting any diversion boxes, processing facilities, or water supplies with the tank farm. All connecting pipes are blanked and sections of connecting pipes removed at both the tank farm diversion box and processing facility ends to assure that liquids cannot possibly flow either to or from a tank farm.

- The amount of fission products included in each salt cake is so limited by chemical separation and/or decay that the heat of radioactive decay can be dissipated naturally to the environment without exceeding a maximum temperature of $260{ }^{\circ} \mathrm{C}\left[500^{\circ} \mathrm{F}\right](5)$ in the salt cake. The assumed radionuclide contents of interest in a salt cake at the time of solidification are summarized in Table 1.

TABLE 1. Radionuclide Contents of a Salt Cake in a Single Tank (6)

Radionuclide Typical Inventory, $\mathrm{Ci}$ Maximum Inventory, $\mathrm{Ci}$

$\begin{array}{rcr}137 \mathrm{Cs} & 3 \times 10^{5} & 3 \times 10^{6} \text { tota } 1 \\ 90 \mathrm{Sr} & 3 \times 10^{5} & 400 \\ 239 \mathrm{Pu} & 200 & 600 \\ 241_{\mathrm{Pu}} & 40 \\ 241_{\mathrm{Am}} & 300 & 40\end{array}$

The $240 \mathrm{pu}$ radionuclide content of the waste is several times less than the ${ }^{239} \mathrm{Pu}$ inventory, while the ${ }^{242} \mathrm{Pu}$ radionuclide inventory is several orders of magnitude less than the ${ }^{239} \mathrm{Pu}$ inventory. The ${ }^{240} \mathrm{Pu}$ and $242 \mathrm{Pu}$ radionuclides do not contribute significantly to the hazards associated with this stored waste. The ${ }^{241}$ Am inventories are a function of the age of the waste. The values given in Table 1 are for waste aged sufficiently to permit filling the tank dome with sand (10 to 20 years).

- The other radionuclides present after the 10 to 20 years of decay are of minor concern compared to the ${ }^{137} \mathrm{Cs},{ }^{90} \mathrm{Sr}$, 
${ }^{239} \mathrm{Pu},{ }^{241} \mathrm{Pu}$, and ${ }^{241} \mathrm{Am}$. Control of these radionuclides will also provide adequate control for the minor quantities of the other fission products still present in the waste.

- The maximum inventory of radionuclides stored as salt cake at a single tank farm is given in Table 2. These values were obtained by multiplying the typical tank inventory as shown in Table 1 by 36 , the number of tanks in the largest tank farm.

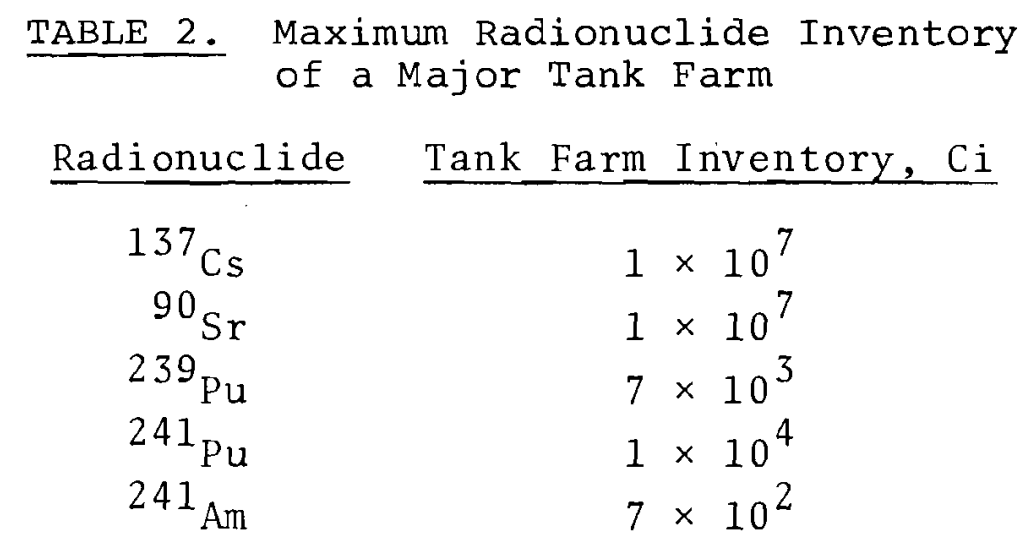

- Administrative controls are established and maintained to control personnel access and activities at the waste storage area. Appropriate waste storage area markers are in place.

\section{INHERENT STABILITY AND CRITICAL MASS}

No mechanisms or reactions from within the salt cake or its immediate environment that might lead to hazardous explosive or poisonous conditions at the surface of the tank farm or in the soil materials around the salt cake have been disclosed.

Although the steel and concrete tanks will inevitably deteriorate over the centuries, the tank materials will remain essentially in place about the salt cakes. Once the salt cake is formed, little interaction between the tank, the soil, and 
the tank contents is foreseen. No inherent mechanisms other than the extremely slow diffusion mechanisms, are present to move the steel or concrete. Very slow interactions driven by concentration gradients will continue between the salts and the tank components (and later, the soil) for centuries.

Filling of the tank dome with solid material such as sand or grout will leave no large open spaces for the accumulation of explosive, poisonous, or other gases, and will provide structural integrity to assure against a future collapse of the tank dome and overburden. Under atmospheric pressure the void volume of a sand-filled tank would not support combustion in an explosive manner. There appears to be no solid state reactions in the salt cake which might lead to the generation of explosive compounds. The waste will be under close surveillance until its temperature has reached a maximum and started to decline. The potential for the generation of any explosive gases by radiolytic reactions is to be evaluated as a part of the program of preparing salt cake waste for longterm storage.

The radionuclide content of the dry and liquid waste will be controlled by chemical separation and removal of high heatgenerating radionuclides, or by allowing sufficient time for decay of these radionuclides. The normal planned salt cake temperature will be 1 imited to $150^{\circ} \mathrm{C}$. A maximum salt cake temperature of $260^{\circ} \mathrm{C}$ may be permitted. Prior to evaporation, a representative sample of the contents from each tank will be collected, dried, and heated to temperatures of $260^{\circ} \mathrm{C}$ to assure that no significant exothermal reactions occur. Preliminary studies have indicated the exothermic reaction most likely to be encountered is the decomposition of ammonium nitrate, possibly at about 240 to $260^{\circ} \mathrm{C}$ in concentrated ammonium nitrate solutions. (7) only a small quantity of ammonium 
nitrate is distributed throughout these wastes and no significant exothermic reaction is anticipated at the $260^{\circ} \mathrm{C}$ temperature. The planned operating temperature of $150^{\circ} \mathrm{C}$ provides a safety range of slightly over $100^{\circ} \mathrm{C}$ during the evaporation and initial storage period. It should also be noted that the salt cake temperature is well below the ${ }^{137} \mathrm{Cs}$ volatilization temperature of about $670^{\circ} \mathrm{C}$.

Although several kilograms of plutonium may be present in a waste tank or salt cake, the plutonium is widely distributed over the 75-ft diam of the tank. The plutonium will be in the bottom layers associated with other metal oxides that precipitated as the tank was filled. The sequential nature of the waste additions will also have provided some depth distribution within the tank. If the maximum plutonium inventory of about $7 \mathrm{~kg}$ is assumed to be in the bottom one centimeter of the tank, its concentration would be between 1 and $2 \mathrm{~g} / 1 \mathrm{iter}$. Criticality is not possible for plutonium concentrations below $7.8 \mathrm{~g} / 1$ iter, the minimum critical concentration for an infinite $\mathrm{Pu}-\mathrm{H}_{2} \mathrm{O}$ system. In the flat disc geometry of the $75-\mathrm{ft}$ diam tank, the minimum critical mass is about $1200 \mathrm{~kg}$ of plutonium in a uniformly distributed slab 6 in. thick, at a plutonium concentration of $16 \mathrm{~g} / 1$ iter of solution. The minimum critical mass for a $\mathrm{Pu}-\mathrm{H}_{2} \mathrm{O}$ system, of course, is $0.52 \mathrm{~kg}$. This amount of plutonium would have to accumulate by some mechanism into a sphere of about $12 \mathrm{in.}$ in diam and in a concentration of $33 \mathrm{~g} /$ liter to become critical. The plutonium concentration in the tank would be substantially less than $6 \mathrm{~g} / 1 \mathrm{iter}$, the always safe concentration, and lack of concentrating mechanisms would assure the avoidance of any assembly of a critical mass of plutonium or other fissionable radionuclides. (8) The addition of poisons for criticality prevention is not considered necessary. 


\section{EXTERNAL FACTORS}

\section{WEATHER}

The potential for wind erosion, water precipitation and evaporation, flash floods and major floods of the Columbia River to disrupt buried salt cake wastes and to produce radiologically hazardous conditions were evaluated and found to be either controllable or insignificant.

Wind Erosion

The semi-arid climate of the region including the Hanford Reservation supports only a sparse cover of sagebrush and other perennial plants and grasses. Because of this dry climate and sparse vegetation, the ground surface over much of the project area is susceptible to long-term wind erosion. In the process of removing sand and smaller-sized particles by deflation, materials are sorted according to size and the coarse materials are left behind. These concentrations of pebbles, cobbles, and boulders form a stable surface against which further erosion by the wind is reduced to essentially zero. Such stony surfaces are commonly referred to as desert pavement or desert armor.

The material undergoing transport by the wind is subjected to a winnowing effect; the coarse materials (sand) is deposited over the project surface in the form of dunes, while the fine grained materials (silt and clay) are removed further afield, generally off the project area. The sand dunes present on the Hanford Reservation are slowly migrating downwind where the sand is eventually blown into the Columbia River and is swept downstream by the current. All of the sand dunes on the Hanford Reservation migrate over a more stable surface of grave1s.

Over long periods of time, wind erosion will continue to modify the topmost land surface over the Hanford Reservation. 
During the past 10,000 to 15,000 years, it appears that only one to $2 \mathrm{ft}$ of surface material were removed where coarse materials are also present. Moreover, many dunes that evidently were active in the altithermal period (4000 to 8000 years ago) have been stabilized by the slightly increased precipitation since that time. $(9,10)$ In the areas encompassing the tank farms, a massive overburden removal of up to $30 \mathrm{ft}$ would be required to expose even the uppermost portion of a salt cake.

It may be helpful to provide a stabilizing ground cover in addition to the naturally occurring coarse grained materials present in the sediments overlying these waste tanks. To maximize the protection against wind erosion, the covered area should extend beyond the bounds of the tank farm itself. The storage area should be inspected on a periodic basis (perhaps annual1y), and any resulting damage in and around the ground cover should be repaired. The ground cover need not be designed to be impervious to water.

The consequences of such an unlikely event as wind erosion uncovering a portion of a salt cake waste storage area are developed in detail in Appendix A. The conditions presented are the maximum hazardous conditions that could exist. Dispersed radionuclides would be found in a narrow path from the radionuclide source if the release occurred over a short period of time such as a few hours. For release times occurring over tens of hours, factors such as variability in wind directions would lead to larger contaminated areas, but at lower radionuclide concentrations.

This postulated event could lead to the following conditions and possible actions: 
- Evacuate people within a distance of about three miles downwind

- Confiscate crops for several years within a distance of about 20 miles downwind

- No external exposure problems would be encountered at distances more than a few hundred yards from the exposed salt cake

- Lung intakes would be less than the most restrictive maximum permissible body burdens at distances beyond a few miles downwind.

In spite of the analysis, there is essentially no potential for an erosion problem to lead to the dispersal of radioactive materials where ground cover protections and appropriate periodic inspections are provided for the waste storage area.

Water Effects

Recorded weather observations and geologic and hydrologic studies indicate no evidence of extreme weather conditions since the last ice age $(10,000$ years ago) posing a significant threat to the integrity offered by the In-Tank-Solidification waste storage concept. (11) Indeed, geologic and paleontologic evidence summarized by Brown and Brown ${ }^{(10)}$ records a marked drying and warming trend from about 12,000 years ago, culminating in the altithermal period from about 4000 to 8000 years ago. Current climates appear comparable to those of about 8000 years ago. Since essentially all water deposited as rain evaporates rather than percolates to the water table, water erosion of the salt cake will not result in the release of large quantities of radionuclides into exposure pathways. The slow leaching of the salt cake by infiltrating rainfall (if in fact significant moisture from rainfall should reach the salt cake, leach radionuclides, and continue downward) would result 
in a slow radionuclide release rate. Once the radionuclides have been leached from the salt cake, soil sorption mechanisms retarding cation movement in the soil would limit radionuclide movement to a rate two to five orders of magnitude lower than that of the water percolation. If needed, a method for immobilizing slow-moving, high concentrations of radionuclides in the unsaturated zone by grout injection, which seals the soil to minimize or to prevent further flow, is available.

The rainfall on the Hanford Project averaged over the last 52 years is 6.4 in. per year with a maximum recorded annual value of 11.45 in. The maximum rainfall observed over shorter time periods was about 3 in. for a month, 2 in. for $24 \mathrm{hr}$, and $0.55 \mathrm{in}$. for a 1 -hr period. $(13,14)$

Because of the dry, semi-arid conditions existing for the last 10,000 years in the Hanford area, the soil has dried to the extent that capillarity will retain about $7 \%$ by volume of additional water above the water table. $(15,16)$ studies are presently in progress to define moisture redistribution in local soils due to typical alternate wetting and drying periods. Although analytical solutions of the complex phenomena are not yet available, data gathered from many years of laboratory and field experience relating to radionuclide migration rates produced by soil drainage provide a good view of occurrences in this area under typical conditions. Field experience utilizing the gamma-scintillation probe and drilling samples consistently shows the maximum downward migration rates for such poorly-sorbed ions as ruthenium to decrease from several feet per year immediately after disposal facility retirement (cribs and trenches) to several inches per year just a few years later. The relatively rapid initial rate is due to the high liquid-waste loading of the subsoil at the time of facility retirement. The subsequent very slow rate 
BNWL - 1194

(inches per year) is probably still chargeable, primarily, to waste liquid drainage rather than to rainfall effects. If a rate of several inches per year is assumed, several centuries would be required for even poorly sorbed ions to migrate from the salt cake to the regional water table. The diffusion coefficient, calculated from two diffusion experiments for plutonium diffusion through Hanford type soils under conditions of unsaturated flow, is $4.8 \times 10^{-12} \mathrm{~cm}^{2} / \mathrm{sec}$. (17) This diffusion coefficient value indicates movement of plutonium at the rate of about $8.5 \mathrm{~cm}$ per each half-life of decay $(24,000$ years). It is apparent that diffusion movement is a negligible mechanism for transfer of plutonium from the salt cake to the ground water. Similar studies for ${ }^{90} \mathrm{Sr}$ and ${ }^{137} \mathrm{Cs}$ show negligible transport by diffusion mechanisms. (18) Some form of saturated flow will be necessary to attain a more rapid rate of plutonium movement. Saturated flow conditions do not currently exist and are not anticipated. The higher soil sorption efficiencies realized for the long-lived radionuclides of concern in this study would extend this travel time by perhaps several orders of magnitude so that the mechanism of radioactive decay will prevent the transfer of radionuclides to the ground-water table in radiologically significant amounts by the intermittent action of rainfall. These same favorable soil sorbtion properties would also be effective in prolonging travel times for any radionuclides entering the water table before they can be discharged into public access surface streams.

For soil that will retain $7 \%$ of additional waters, an essentially instantaneous infiltration of $14 \mathrm{ft}$ of water is required to provide near saturated flow conditions between the top of the soil surface and the ground water table at a depth of 150 to $200 \mathrm{ft}$. If only the $150 \mathrm{ft}$ of soil column between the bottom of a salt cake and the ground water table is considered, a rapid application of $10.5 \mathrm{ft}$ of water (126 in.) would be required to initiate 
appreciable flow. Such large amounts of water have not been available to the 200 Area Plateau since the close of the last ice age. No environmental conditions or human endeavors are known that might make an application of 126 in. of water to the 200 Area plateau possible. The current average rainfall rate of 6.4 in. per year has not led to significant migration due to drainage. In fact, the current status of soil dryness has resulted during the average rainfall period.

For the sake of this hazard analysis, consider that the soil column under the salt cake has, by some mechanism, become more saturated and that water is continually supplied to provide a transport mechanism for radionuclides in the salt cake to the ground water table. Under such conditions, what would be the concentration of radionuclides in the ground water? For the salt cake under consideration, the plutonium concentration is about $8 \times 10^{-2} \mu \mathrm{Ci} / \mathrm{cm}^{3}$ of salt cake, or about $5 \times 10^{1} \mu \mathrm{Ci} / \mathrm{cm}^{2}$ of projected area. Adsorption experiments have shown that, for basic plutonium deposits, 20 volumes of water are required to leach $0.1 \%$ of the plutonium from 1 volume of soil. (17) With $1 \mathrm{~N} \mathrm{NaNO}_{3}$ solutions such as could result from the salt cake composition, 20 volumes of water may leach $5 \%$ of the plutonium from 1 volume of soil. (17) For a ground water depth of $150 \mathrm{ft}$ and a leach rate of $0.1 \%, 20$ volumes of water would deliver plutonium at a concentration of about $6 \times 10^{-7} \mu \mathrm{Ci} / \mathrm{cm}^{3}$ to the ground water table. For a leach rate of $5 \%, 20$ volumes of water would deliver plutonium at a concentration of $3 \times 10^{-5}$ $\mu \mathrm{Ci} / \mathrm{cm}^{3}$ to the ground water table. The $168-\mathrm{hr} M \mathrm{MPC}_{\mathrm{w}}$ for ${ }^{239} \mathrm{Pu}$ is $5 \times 10^{-5} \mu \mathrm{Ci} / \mathrm{cm}^{3}$. Dilution in the ground water and sorption as the plutonium travels through the soils, virgin with respect to plutonium, would reduce these already drinkable water concentrations many orders of magnitude before the flow reaches the Columbia River. $(19,20)$ These calculations indicate that direct pumping from ground water wells located 
directly under a salt cake would produce water with ${ }^{239} \mathrm{Pu}$ concentration below the recommended 168 -hr $M_{\mathrm{WPC}}$. The concentration of ${ }^{241} \mathrm{Pu}$ and ${ }^{241} \mathrm{Am}$ concentrations are even lower in relation to their $\mathrm{MPC}_{\mathrm{W}}$ than these calculated for ${ }^{239} \mathrm{Pu}$.

Similar calculations were made for ${ }^{137} \mathrm{Cs}$ and the ${ }^{90} \mathrm{Sr}$ in the salt cake. Experiments show that 42 and 12 volumes of water leach $0.01 \%$ of ${ }^{137} \mathrm{Cs}$ and ${ }^{90} \mathrm{Sr}$ from one volume of soil, respectively. (18) These leaching rates would deliver a ${ }^{137} \mathrm{Cs}$ concentration of $4 \times 10^{-5} \mathrm{\mu Ci} / \mathrm{cm}^{3}$ and a ${ }^{90} \mathrm{Sr}$ concentration of $1 \times 10^{-4} \mu \mathrm{Ci} / \mathrm{cm}^{3}$ to the ground water. The $168-\mathrm{hr} M \mathrm{MPC}_{\mathrm{w}}$ for ${ }^{137} \mathrm{Cs}$ and ${ }^{90} \mathrm{Sr}$ are $2 \times 10^{-4} \mu \mathrm{Ci} / \mathrm{cm}^{3}$ and $10^{-6} \mu \mathrm{Ci} / \mathrm{cm}^{3}$, respectively. Hence, the ground water ${ }^{137} \mathrm{Cs}$ concentrations would always be less than the $168-\mathrm{hr} \mathrm{MPC}_{\mathrm{W}}$. However, the ${ }^{90} \mathrm{Sr}$ concentration at the point of entry into the ground water systems could be 100 times the $168-\mathrm{hr}_{\mathrm{MPC}}$. It should be recalled that this analysis has reviewed a hypothetical occurrence and has not detailed factors such as sorption on the $150 \mathrm{ft}$ of soil column between the salt cake and the ground water, the time required for this travel and the reduction in radioactivity due to decay that would have occurred, and the slow water application that would be required to result in equilibrium between input water and the salt cake. It does appear that for ${ }^{239} \mathrm{Pu}$, ${ }^{241} \mathrm{Pu},{ }^{241} \mathrm{Am}$, and ${ }^{137} \mathrm{Cs}$, the amount of input water required to remove these radionuclides from the salt cake would also dilute their concentration to below the $168-\mathrm{hr} \mathrm{MPC}_{\mathrm{w}}$. For ${ }^{90} \mathrm{Sr}$, an additional dilution factor of 100 is required to lower its concentration below the $168-\mathrm{hr} \mathrm{MPC}_{\mathrm{w}}$. Due to these conditions, there seems to be no reason to doubt that this additional dilution would occur.

Once in the ground water, the migration rate of these radionuclides is slow. This slow transport rate provides time for additional decay. As measured in the laboratory under simulated natural conditions, the measured migration rates are 0.01 , 
BNWL -1194

0.001 , and 0.00001 the rate of ground water movement for ${ }^{90} \mathrm{Sr},{ }^{137} \mathrm{Cs}$ and ${ }^{239} \mathrm{Pu}$, respectively. $(17,18)$ A ground water pathway to the Columbia River or to a well that provides three years for ground water travel will yield ${ }^{90} \mathrm{Sr}$ decay of 10 halflives, ${ }^{137} \mathrm{Cs}$ decay of 100 half-1ives, and ${ }^{239} \mathrm{Pu}$ decay of 10 half-lives. At ground water distances three years flow time from the salt cake, a11 ${ }^{90} \mathrm{Sr}, 137 \mathrm{Cs}$, and ${ }^{239} \mathrm{Pu}$ will have decayed to insignificance.

In summary, one may conclude that surface waters from rain and snow will not transfer radionuclides from the salt cake to the ground water. Under foreseeable climatic conditions, there is no identifiable mechanism for transporting salt cake radionuclide waste materials to the ground water table in significant amounts as compared with generally accepted guides for public protection.

\section{Flash Floods}

In some topographical conditions, flash floods may move substantial amounts of material and dig deep runoff paths in an overburden. The potential of flash floods uncovering or doing damage at the 200 Area Plateau is extremely remote. Figure 1 showed the major feature of the 200 Area Plateau. There is no current evidence of previous flash floods (later than 10,000 years ago) in the 200 Area Plateau where the wastes are buried. The high land contours at the burial ground areas offer substantial guarantees against flash flood damage in these areas. The most likely flash flood channels are in the Cold Creek Valley, 3 to 5 miles from the burial sites and are 20 to $40 \mathrm{ft}$ lower in elevation than the burial sites. The Cold Creek Valley shows no evidence of flash flood runoff resulting in a continuous flow of water through the valley at any time within the last 10,000 years. $(10,21)$ climate changes leading to large increases in snowfall on the eastern slope of the Rattlesnake Hills, the Yakima Ridge, and in the upper Cold Creek Valley, 
and followed by rapid melting would seem to be required to result in flash floods of any type. Even these conditions would not produce flash flood effects at the waste storage locations.

It is conceivable that overburden erosion by local water runoff over centuries of time could expose the waste, although no single postulated event would be of significant consequence. Inspection and possible maintenace by overburden replacement on a periodic basis would be prudent to assure long-term storage. This inspection and "replacement-ifnecessary" program covers erosion from both wind and water. The consequences of local runoff water erosion uncovering the waste are considered to be minor. The radionuclides would be sorbed on the soil as the water moves away from the salt cake. The flow of surface water would be local and would soak into the soil before reaching the river. Some amount of radioactive material could become airborne after the water dries away. However, the sorption on the soil and in the first few inches below the surface would limit the quantity of radionuclides available for dispersion in the air. The total effects of such a local water erosion event would be confined to an area within a few hundred feet of the burial site.

Major River Floods

No mechanism capable of creating a major river flood of sufficient magnitude to damage the 200 Area Plateau was identified. Even a major break in Grand Coulee Dam would not lead to surface water levels of concern relative to the tank farms. (22) The status of ground water tables after such a flood would not be changed significantly, although some very nominal increase in levels and flow rates would be expected. Past history of the Columbia River valley shows that some massive events (large landslides) have occurred to stop the river's flow far upstream from Hanford, followed by a massive surge of 
BNWL - 1194

flood waters as the earthen and rock dams are washed away. Even an event of this type is not capable of storing up sufficient water and a sufficient water head to affect the tank farm storage facilities. Events capable of inundating the 200 Area Plateau apparently are limited to floods comparable to those of glacial Lake Missoula and related lakes from about 50,000 to 10,000 years ago. $(9,10)$

For the purpose of assessing the hazard associated with major river flooding, it is necessary to define a maximum credible incident with some professional basis considering the following detailed facts:

- The mean annual flow of the Columbia River is about 100 million acre feet.

- The total storage capacity of the entire river, including Mica, Arrow, and the major tributaries and impoundments, such as Libby, is somewhat under 22 million acre feet depending on the operating condition after 1975.

- A flow of 10 million cfs for an entire day represents a s.torage capacity of 20 million acre feet.

On the basis of these physical facts, a coincident failure of Grand Coulee Dam and the simultaneous arrival of breech flows from upper Canadian storage projects, physically separated by as much as 400 miles, would produce a flow of only 10 million cfs past Hanford. Even this flow rate would raise the surface waters to an elevation only $560 \mathrm{ft}$ above sea level, or nearly $100 \mathrm{ft}$ below the lowest tank farm elevation. No combination of circumstances could be hypothesized, including the simultaneous explosion of nuclear warheads on all Columbia River watershed dam projects and the resulting total destruction of a11 impoundments on an instantaneous basis, capable of delivering a sustained flow of 10 million cfs for a 24 -hr period. A flood of this magnitude might scour 15 to $30 \mathrm{ft}$ of river bottom a day out of the existing channel with the result that no estimate 
BNWL - 1194

of the sequence of events could be postulated without much detailed study.

EARTH STABILITY

Seismic Events

The 200 Area Plateau of the Hanford Reservation lies within the Columbia Plateau geologic and physiographic province or, more specifically, within the Pasco Basin of south-central Washington. As described by several investigators and more recently summarized by Jones and Deacon, (23) and by Brown and Brown, (10) the geology is characterized by a great thickness of tertiary basaltic volcanic rocks, upon which rest locally thick sections of late tertiary and quaternary sedimentary strata. Recent work by Raymond and Tillson (24) has shown that over 100 separate flows, present to a depth greater than $10,000 \mathrm{ft}$ beneath the Hanford Reservation, appear to have accumulated in a slowly sinking structural basin at a fairly constant rate for the last 50-60 million years. The sediments resting directly upon the basalt are primarily the Ringold Formation which consists of compact and indurated silts, sands, gravels, clays, and tuffs representing both fluviatile and lacustrine deposition. $(23,25)$ Resting uncomformably upon the Ringold Formation is a varied section of late Pleistocene and early Holocene sediments of glaciofluvial and glaciolacustrine origin ranging from silty clay to coarse gravel. The glaciofluvial deposits are the major foundation material on the Hanford Project. The average seismic velocity of these foundation materials is approximately $2,000 \mathrm{ft} / \mathrm{sec}$ (23) Housner (26) states that "No adverse seismic effects are anticipated in the glaciofluvial deposits at Hanford, and earthquake ground motion having spectral characteristics similar to recorded California ground motions on firm alluvium can be expected." These sedi ments could transmit locally occurring earthquake displacements to the surface under postulated conditions, but would most 
likely provide some shock protection under the conditions reported for past earthquakes in the region. $(27,28)$ A recent study by Raymond (29) on the simultaneous measurements of ground motion at a number of locations on the Hanford Reservation resulting from quarry blasting at Gable Mountain indicates a logarithmic attenuation in vertical ground acceleration as the distance from the source increases. If a locally occurring earthquake generated a similar energy spectrum, a vertical acceleration of $0.1 \mathrm{~g}$ observed at $100 \mathrm{ft}$ from the source would be attenuated to $1 \times 10^{-5} \mathrm{~g}$ at $10,000 \mathrm{ft}$ from the source.

According to Housner, (26) the detailed seismic record indicates that the Hanford Reservation area "has not been subjected to more than weak ground shaking during historical times, and corroborates the estimate that the Hanford area is in a region of moderate seismicity, verging on minor seismicity". On the map of earthquake intensity distribution published by Rassmussen, (30) nearly all the reservation area is included within his zone 1 , in which only minor damage has occurred since 1840. The strongest earthquake within a radius of $150 \mathrm{miles}$ of Hanford during the period of historic record was the MiltonFreewater, Oregon shock of July 15, 1936. It was located approximately 60 miles southeast of Hanford and was rated at Modified Mercal1i VII in intensity and Magnitude $5.7-5.8$. According to Neuman (31) the Hanford area experienced on $1 \mathrm{y}$ mild ground shaking corresponding to an intensity of MM-IV, or an acceleration of less than $0.007 \mathrm{~g}$, as a result of the MiltonFreewater earthquake. Housner (26) states that the maximum acceleration for a Magnitude 5.8 shock at a distance of 60 miles would be $0.05 \mathrm{~g}$, or seven to eight times greater than that actually experienced. Housner further states that ian earthquake similar to the 1936 Milton-Freewater shock occurring along the northwestern end of the fault would produce shaking at the Hanford site equivalent to $0.15 \%$ design spectrum". (The 
northwest end of the fault alluded to by Housner is in the Rattlesnake Hills.) This shock would be equivalent to an intensity of MM-VIII at Hanford, based on the GutenbergRichter Formula where intensity equals three times the $10 \mathrm{~g}$ of the acceleration plus 1.5, and appears to be extremely more conservative than the records warrant. Among the other shocks recorded during the past century with inferred Magnitudes of 4.5 or greater, only two occurred within 50 miles of the site (Housner). (26) One of these reportedly damaged some buildings in Umatilla, Oregon on March 6, 1893, but was not reported in the Hanford area. The other earthquake, probably centering in the vicinity of Corfu on the east end of the Saddle Mountains and within 10 miles of the Hanford area, occurred on November 1,1918 , and can be regarded as the major historic shock within the context of this study.

Ground shaking during the Corfu earthquake was felt over a wide area, but various reports of damage and landslides in the Saddle Mountain area are in serious conflict. Fifer, (32) on the basis of interviews with people who resided in the area in 1918, presents good evidence that the intensity at Corfu was less than MM-IV and on the Hanford Reservation area was probably less than MM-II to III. He also reports that the original record of the quake, Bulletin of the Seismological Society of America, Volume 8 , indicated an intensity of IV on the RossiForel scale in use at that time. A Rossi-Forel intensity IV-V is equivalent to an MM-IV whose description matches closely the eye witness accounts. Jahns (25) cites lack of physical evidence of damage to any of the buildings or structures built prior to 1918 and still present in the Corfu area as further indication that the 1918 quake was of only low to moderate intensity, and probably did not exceed Magnitude 5.0. In a recent report, Housner (33) derived earthquake probabilities for the Hanford region. His analysis was based on the number 
of earthquakes known to have occurred in a circular area of 100 mile radius centered on Hanford. The probability of earthquakes occurring in southeastern Washington is shown to be once in $1,850,4,000$, and 16,700 years, with accelerations of $0.1 \mathrm{~g}$, $0.15 \mathrm{~g}$, and $0.2 \mathrm{~g}$, respectively. A shock of $0.10 \mathrm{~g}$ or greater within the 31,400 square miles considered in the analysis would most likely occur along such, as yet, ill-defined structures as that on which the Milton-Freewater, Oregon quake occurred. Housner also indicates that weaker ground motion exceeding $0.025 \mathrm{~g}$ in southeastern Washington could be expected on the average of about once in 60 years when considering earthquake magnitudes greater than 4.5 and less than 8.5 .

Jones and Deacon (23) conclude that "tectonic processes resulting in major deformation of the earth's crust follow major fault zones without regard to individual geologic or physiographic provinces. Persistently active tectonic zones can be identified by recurrent earthquake epicenters closely spaced along lineations which are related to known and hidden faults. Hanford does not 1 ie in a persistently active seismic zone."

The foregoing conclusion is, in general, consistent with the estimate of moderate seismicity in the Hanford region. Jones and Deacon, however, cite evidence that might indicate the possibility of greater seismicity. In particular, they note two possible fault systems located adjacent to the Hanford Reservation that possibly have had surface displacement in historical or at least geologically recent times. The first of these is the Saddle Mountain fault just north of the Hanford Reservation, which U. S. Geological Survey geologists have mapped and concluded to be of questionable importance. The second is the hypothesized Rattlesnake Mountain-Wa1lula-MiltonFreewater system. The northwestern end of this system is about 10 miles south of the waste storage sites. Ground mapping has 
not validated this as a surface or near-surface fault system, and the located epicenters of recent earthquakes are not along this postulated lineament. Some investigators have hypothesized that that structure follows the Horse Heaven Hills westward to Wallula Gap, then northwestward along the Rattlesnake Hills. Data supporting that extension are almost solely topographic, and evidence contra-indicating the extension are summarized by Brown $(9)$ and by Brown and Brown. (10) Brown (9) tabulates eight very minor shocks detected at Hanford that appears to lie along an east-west zone more nearly coinciding with the Horse Heaven Hills. The report by Jahns (34) describes the results of a follow-up investigation specifically aimed at assessing the significance of these two geological features. Jahns concludes that "no evidence of recent or historic ground displacement has been recognized along the trace of any fault in the Hanford region. Features previously cited as constituting such evidence are significantly different--in form, in attitude, and in location with respect to known or inferred faults-from comparable features that do represent active faults in other regions. All of them can be readily explained in terms of geologic processes not necessarily associated with faults, and some of them occupy ground where there is direct evidence against the existence of faults." Jahns also recommends "that seismic design of structures within the Hanford nuclear facility be compatible with the possibility of moderate to moderately strong ground shaking from future earthquakes in the Pasco Basin and adjacent areas. The distribution and nature of faults in the region suggests that a local earthquake of Magnitude 5.5 is the strongest that reasonably could be expected. The posibility of surface ground rupture due to upward propagation of displacement along any fault in the Hanford facility area is so remote that it can be safely disregarded." $(34,35)$ Jahns $(34)$ apparent1y considers that a 1ocally occuring earthquake of Magnitude 5.5 would produce an intensity 
of MM-VII, similar to the 1936 Milton-Freewater, Oregon shock. The similarity of the basement rocks suggests that this would be a reasonable and perhaps the only assumption that could logically be made on the basis of the limited seismic record. The surficial and/or foundation material on the Hanford Reservation, however, is not the same as the material occurring in the Milton-Freewater, Oregon area. Therefore, any correlation between predicted earthquake magnitudes and response intensities for the Hanford Reservation could be seriously misleading. Neuman $(31)$ indicated that the Hanford Reservation is in an area of southeastern Washington that shows smaller response to distant shocks of destructive magnitude than do surrounding areas. Other more recent studies, particularly by Raymond, ${ }^{(29)}$ tend to confirm this. Therefore, Neuman's (31) recommendation that an intensity of MM-VI be used as a "sound working value of assumed intensity for engineering purposes," would be a more realistic assumption while acknowledging the extremely remote possibility of experiencing an earthquake intensity of MM-VII. An acceleration of approximately $0.07 \mathrm{~g} / \mathrm{sec}^{2}$ produced at any locale in question by an earthquake of MM-VIIII would be insufficient to alter the ground surface. Earthquakes with intensities exceeding MM-VIII usually have accompanying ground cracking and fissures.

Earth Slides

Increased rainfall or irrigation could lead to minor landslides or ground swells along banks of the Columbia River in the Hanford region. However, neither the magnitude nor location of these disturbances are regarded as a threat to the integrity of the long-term waste management program.

The filling of the pool behind the proposed Ben Franklin Dam site near Richland, Washington could result in some bank slides into the river. Some slide activity, all relatively minor, has been recently observed. 
The river banks where slides are most likely are on the river side opposite from the Hanford Complex. The gentle slope of the land on the Hanford side of the river prevents these slides from forming a dam of sufficient size to retain and significantly increase the water level of the river. The most extensive slide that can be postulated might cause some very low-level pooling of the river and might fill the present river channe1. Slide material volumes approaching one million cubic feet would be required to produce river pooling. The river would immediately begin to wash away the slide material composed of sand, small gravel, and rocks of a few inches maximum diameter. If one assumes the slide material is able to block the river channel at a river flow rate of 150,000 cfs (normal flow rates range from 50,000 to 400,000 cfs), then a river elevation rise of a few feet to a few tens of feet would result. This rise would result in surface water moving a few hundred to a maximum of a few thousand feet toward the 200 Area Plateau. of course, the slide fill would quickly be washed out and the river would soon return to approximately its former flow path. While such action could be of concern for river bank installations, no net effects from such an event would be evidenced at the 200 Area Plateau.

Irrigation projects near the banks of the Columbia River may contribute to some small landslides on the river banks. Increased water loading of the high irrigable ground may cause additional slides. No irrigation projects are now sufficiently near the waste storage areas to produce significant changes in the ground water or surface water flow patterns or rates. The effects of any slides resulting from irrigation programs would be similar to those that might result from the formation of the Ben Franklin Dam pool. 
BNWL- 1194

GROUND WATER

A major factor in the overall assessment of the safety of storing radioactive wastes on the Hanford Plateau is the extremely slow migration rate of any radionuclides through the unsaturated soils above the ground water table. The decay period afforded in this zone will be, of course, directly proportional to the depth of the relatively dry soil column above the water table.

Ben Frank1in Dam

The flow system analysis phase of the Ben Franklin Dam study indicates that installation of the dam would significantly affect the water table elevation, flow paths, and travel times of the ground water under the 200 Area i'lateau. (36) Figure 3 shows the proposed location of the Ben Franklin Dam, the streamline flow paths of the ground water, and the water table contours in feet above mean sea level. The most pronounced effects would be experienced, as expected, in the immediate vicinity of tho dam. Maximum increases in the steady-state water table elevations of 20 and 25 it for 200 West and 200 East Areas, respectivejy, are predicted for the maximum reservoir elevation of 400 fit above mean sea level and a columbia River flow rate of $150,000 \mathrm{cfs}$. The lower reservoir elevation considered, $385 \mathrm{ft}$ above sea level, and lesser river discharge rates would have correspondingly less effect on water table increases, flow paths, and travel times.

The most noticeable change predicted for ground water flow paths would be for water migrating from beneath 200 East Area. The low level disposal sites in the 200 East Area, with the dam in place, are near the predicted ground water stagnation point. Thus, water movement in this area is sensitive to relative small changes in system conditions. The study results indicate that, with the dam in place, ground water from the 


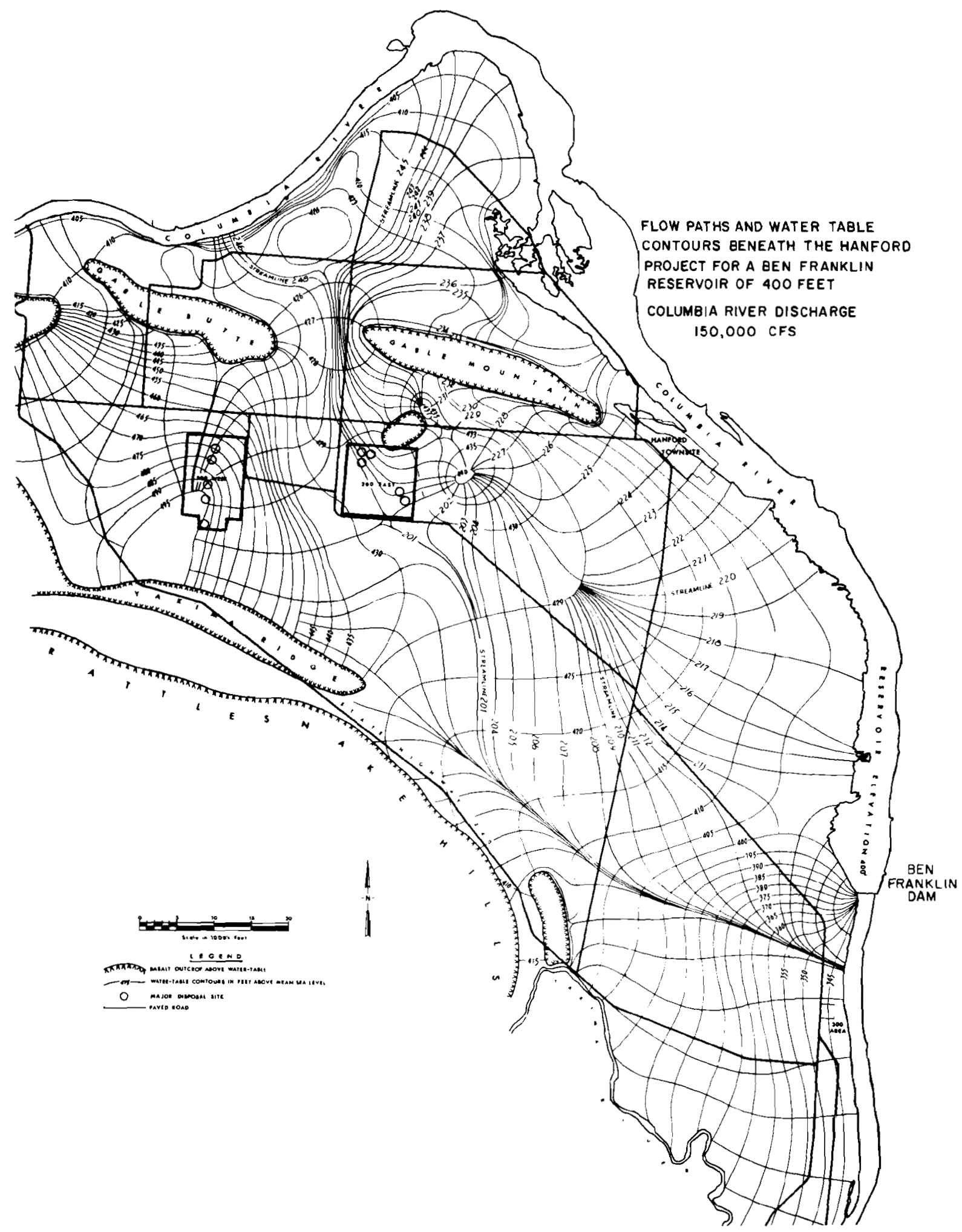

FIGURE 3. Ben Franklin Dam Water Contours 
northern part of the area may no longer flow south and east toward the river, as at present, but could flow northward through the Gable Butte-Gable Mountain gap and subsequently into the river near the 100 Areas. The flow system analysis and past ground water monitoring data indicate this path as one presently taken by waste cooling water discharged to the Gable Mountain Swamp northeast of. 200 East Area.

Water discharged to the ground in the vicinity of the Gable Mountain Swamp would flow northeasterly toward the river. The travel time of the ground water to the river along this flow path is the shortest predicted for water moving from any location in or near 200 East Area--about three years. The migration rate of any radionuclides reaching this flow path would be orders of magnitude less than the water flow rate, as indicated earlier.

The expected flow routes for wastes from the 200 West Area disposal sites would also be northward to the river. Along such paths, the travel times are only slightly shorter than along the southern flow paths of the present ground water flow system, and minimum trave1 times would not be appreciably different than under present conditions. The analysis does not reveal the existence of any untenable conditions with regards to 200 Areas waste management operations due to the construction of Ben Franklin Dam.

Irrigation

General quantitative statements cannot be made on the detrimental or beneficial effects of irrigating any specific area without detailed simulation modeling. The relatively complex nature of the ground water flow system requires that the areas considered for irrigation (or other type of water amendment) be specified along with a probable ground water recharge rate. 
When considering the very long periods (centuries) of concern in this long-term storage hazards analysis, one needs to include in any evaluation the distant future changes in the ground water flow regime due to irrigation and other possible factors. The effects of irrigation on various sectors of the Hanford Project were evaluated by simulation techniques to estimate water table elevation and flow characteristics, particularly in the vicinity of the 200 Areas. Qualitatively, irrigation of any sizeable area on the Hanford Project could, depending upon the location and size of the area irrigated, increase the water table elevation beneath the 200 Areas to varying degrees. The least pronounced effect would result from irrigating areas close to Richland. The most pronounced water table elevation increases would result from irrigation of areas west of the 200 Areas and, to a somewhat lesser degree, from areas immediately east of the 200 Areas using water from an outside source such as the Columbia River. The effects of using ground water from wells west of the 200 Areas were not evaulated. However, controlled sprinkler irrigation using ground water "upstream" from Hanford conceivably could be developed to actually improve ground water management.

Changes in ground water travel times are even more difficult to forecast. Flow paths and associated travel times from the 200 Areas toward surface waters (Yakima and Columbia Rivers) are dependent upon the ground water gradients and the water permeability of the soil materials along the flow paths. Generally, as the water table rises, water enters materials more permeable than are the presently saturated aquifers (indicative of a faster travel time). However, a thicker aquifer resulting from a raised water table can transmit comparable water volumes at lower average flow rates. An increase or decrease in the ground water gradient depends upon the area irrigated, whether the irrigation water is obtained from the ground water or a distant source, and the integrated effects 
of such irrigation upon the entire system. Qualitatively, any changes should be avoided that might cause potentially contaminated ground waters under the 200 Areas to enter the permeable flow channels along either side of Gable Mountain. Nominal present flow times from 200 East Area to the Columbia River along some particular paths near Gable Mountain are only a few years. Also, the ion exchange capacity of the relatively coarse materials (sands and gravels) in these channels is less than that found elsewhere.

\section{EXTERNAL EXPLOSIONS}

Impact Crashes

It is possible to postulate events such as airplane crashes and accompanying surface explosions or impacts that might remove or penetrate the waste tank overburden. Once the tank dome is filled, external impacts from small propeller driven aircraft would not generally be able to penetrate the overburden and reach the salt cake. Jet aircraft could be expected to penetrate to 40 or more feet, depending, of course, on aircraft type and the impact conditions. Fires and possible explosions could be expected to follow such a crash, although frequently for these types of impacts the aircraft is highly compacted with little or no debris spread more than a few hundred yards from the impact site.

One may estimate the probability of such an accident by assuming the number of the accidents of this type per year and the area over which they occur. If one makes the liberal assumption that 10 plane crashes of high surface impact occur per year over an area the size of the United States, and that the area of the tank farms available for possible impact is 0.1 square miles, then the probability ${ }^{(37)}$ of a tank farm hit is: 
BNWL - 1194

$$
P=1-\left(1-\frac{a}{A}\right)^{N}
$$

where $P$ is the probability of a tank farm hit in any given year

a is the area of the tank farm, $0.1 \mathrm{sq}$ miles

$A$ is the area of the United States, $3 \times 10^{6} \mathrm{sq}$ miles

$\mathrm{N}$ is the number of high impact aircraft crashes per year, 10

$\mathrm{p}$ is equal to $3 \times 10^{-6}$ per year.

This calculation assumes every part of the United States has an equal probability of experiencing a high impact aircraft crash. This calculation is clearly conservative, since all commercial aircraft are required to fly on assigned courses and, at least currently, these courses do not overfly the Hanford Complex. A1so, the military aircraft overflights are not routine. The conservative assumptions tend to overestimate the probability. The actual probability is 1 ess than $3 \times 10^{-6}$ per year.

Nuclear Weapon Impact

A surface explosion of a nuclear weapon on a tank farm is an unlikely event. However, a nuclear attack merits consideration in view of the aimability and target selectability of an enemy force, and the long time period of interest. A typical tank farm of about $500 \mathrm{ft}$ on a side contains 12 waste storage tanks. Some tank farm complexes may contain as many as 36 tanks and measure about $1000 \mathrm{ft}$ on a side. The minimum sized weapon capable of vaporizing or total1y dispersing a large tank farm complex of $1000 \mathrm{ft}$ on a side for surface burst conditions would be on the order of a few hundred kilotons. If one assumes a direct hit by a 300 kiloton (kT) weapon, then the tank farm contents would be dispersed to the atmosphere and a crater 150 to $200 \mathrm{ft}$ deep would remain. For a major tank farm complex of 36 tanks with an average content as shown for a typical tank in Table 1, the radionuclide inventory shown in Table 2 would be dispersed to the atmosphere. 
For the tank farm inventories considered here, the ${ }^{137} \mathrm{Cs}$ and ${ }^{90} \mathrm{Sr}$ produced by a $300 \mathrm{kiloton}$ weapon would be about $1 \%$ of the total quantities dispersed. A 3 megaton weapon would account for about $10 \%$ of the total quantity of ${ }^{137} \mathrm{Cs}$ and ${ }^{90} \mathrm{Sr}$ dispersed. The weapon contributions of ${ }^{239} \mathrm{Pu},{ }^{240} \mathrm{Pu},{ }^{241} \mathrm{Pu}$, ${ }^{242} \mathrm{Pu}$, and ${ }^{241} \mathrm{Am}$ are neglected in this presentation.

For a 3 megaton nuclear weapon, a size more likely to be used by an enemy, the maximum distances and areas requiring control action are shown in Table 3 . For these considerations, the 3 megaton weapons are assumed to attain all of their power from the fission process. Except for the calculated fallout dose rate, this assumption does not enter into the results of the analysis. Essentially all of the radioactivity dispersed as the result of a tank farm hit originates from the stored waste--not from the weapon.

TABLE 3. Anticipated Maximum Extent of Control Action Required from a 3 MT Weapon

$\begin{array}{ccccc}\frac{\text { Radionuclides }}{137 \mathrm{Cs}} & \begin{array}{c}\text { Distance, } \\ \text { miles }\end{array} & \frac{c}{\text { Area, }} \begin{array}{c}\text { square miles } \\ <10\end{array} & & \begin{array}{c}\text { Possible Action } \\ \text { Confiscate Crops } \\ \text { (one year) }\end{array} \\ { }^{90} \mathrm{Sr} & 300 & 20,000 & & \begin{array}{c}\text { Confiscate Crops } \\ \text { (one year) }\end{array} \\ 239 \mathrm{Pu} & <10 & <10 & & \text { Evacuate People } \\ 241_{\mathrm{Pu}} & <10 & <10 & & \text { Evacuate People } \\ 241_{\mathrm{Am}} & <10 & <10 & \text { Evacuate People }\end{array}$

For a 300 kiloton weapon, the only difference from Table 3 is for ${ }^{90} \mathrm{Sr}$ where the distance and area requiring the control action would become 260 and 15,000 , respectively. Since each weapon is capable of destroying the entire tank farm, the difference derives from the dilution difference between 300 kiloton and 3 megaton weapons. 
The possible action of confiscating crops for one year derives from a ground contamination level of $1000 \mu \mathrm{Ci} / \mathrm{m}^{2}$ and $10 \mu \mathrm{Ci} / \mathrm{m}^{2}$ for ${ }^{137} \mathrm{Cs}$ and ${ }^{90} \mathrm{Sr}$, respectively. It should be clear that this is presented as a possible action to indicate types of actions that might be needed. The conditions and particular crops involved would have to be considered in some detail before deciding on an action plan.

The dose rate due to fallout from the weapons would be greater than the contributions from the ${ }^{137} \mathrm{Cs}$ dispersed from the waste for the first 4 months after the detonations. Twelve hours after the detonations, the weapons fallout at a distance of 200 miles downwind is 15,000 times the ${ }^{137} \mathrm{Cs}$ contribution, at 4 months they are about equal, and at one year the ${ }^{137} \mathrm{Cs}$ from the dispersed tank farm wastes exceeds the weapons fallout contributions by a factor of 10 . For the distance and conditions used in this example, the ${ }^{137} \mathrm{Cs}$ dose rate at 1 year amounts to only $0.2 \mathrm{mrad} / \mathrm{hr}$.

PLANT AND ANIMAL ACTIVITIES

In addition to the physical effects discussed, the possible effect from plant growths and animal activities should be considered. Perennial plants may develop root systems reaching to the depth at which the salt cakes are found. (38) Any moisture centers near the stored waste would attract root systems. The heat from the stored waste might stimulate root growth. Root systems would be expected to develop in a nitrogen-rich nutrient layer about the salt cake where the food, moisture, and temperature are favorable. These root systems would provide a mechanism to transport radionuclides to the plant growth above the soil surface. It would not, therefore, be advisable to permit perennial plant growths over the waste storage location, and farming activities, in particular, would not be desirable. The use of a solid ground cover for wind and water erosion protection could serve to prevent the transfer of 
radionuclides to the soil surface through this biological system. If a porous soil stabilizing overcover is used, a high concentration of copper or other ions that are chemically stable could be used as a total deterrent to plant growth over the waste storage area.

Animal life will not be found below about $10 \mathrm{ft}$. (39) Hence, animals will not burrow into the salt cakes or transfer any of these waste to the soil surface.

One may postulate a case of human encounter with the waste by digging in locations not properly marked and maintained. Maintenance inspection necessary to detect and correct for any wind or water erosion can be extended to assure preservation of the area in an adequately posted and controlled status. Under these conditions, human actions will not lead to unknowingly uncovering or disturbing the buried radionuclides.

\section{RETRIEVAL}

The hazard analysis considerations of indefinite longterm storage, perhaps for hundreds of centuries, differ from the hazard analysis considerations for most nuclear facilities requiring analysis and predictions of events over the useful life of a plant facility, usually 25 years or less. The confidence level of predicting the course of events for a few decades is orders of magnitude beyond that for predictions over hundreds of centuries. It is appropriate, therefore, to consider the questions of retrievability and the alternatives available in case of unforeseen events for such a long-term waste storage concept as that of In-Tank-Solidification.

It may be assumed that currently unforeseeable conditions may develop in the future such that the contaminated solidified salts should be moved to another location. It should also be assumed that the storage tanks will have lost their integrity 
and, consequently, a retrieval and transport program based primarily on the handling of contaminated solids would be needed. There are no insurmountable problems in "mining" and packaging these contaminated solids using currently available technology. Erection of a temporary type containment contamination control building over the salt cake site would probably be required. Shielded or remotely operated shovels could be used to place the salt cake into contamination-tight containers. These containers could be sealed, shielded, and shipped to other waste disposal sites, or transported to nearby facilities such as the Hanford canyon buildings for storage or additional processing. This recovery may become easier at a much later date than is currently envisioned, possibly due to new technologies and equipment, and certain1y due to the decay of the ${ }^{137} \mathrm{Cs}$ and ${ }^{90} \mathrm{Sr}$ inventories.

If such a relocation program were to become necessary, retrieving and moving the buried salt cakes would constitute but a part of a large solid waste recovery program that might include recovery of contaminated tanks, pipelines, burial grounds, and soil from cribs, swamps, and sites of process leakage. The reactor buildings and the chemical processing plant buildings also contain significant amounts of radionuclides constituting a retrieval problem somewhat similar to the radioactive materials in the tanks. The objectives and requirements of any future relocation program would determine the degree of relocation required. No new or unique retrieval problems are generated by adopting the In-Tank-Solidification concept.

It appears that any conditions that might pose a hazard to the stored waste would develop over a period of years. Through periodic observations, the changing conditions should be detected. Actions to reverse or prevent impending changes in storage conditions, or to retrieve, reprocess, or relocate the sa1t cake waste could be planned, initiated, and completed in a timely manner to avoid the consequences of the developing hazards. 


\section{ACKNOWLEDGEMENT}

The generous efforts of my many colleagues of BattelleNorthwest and of the Atlantic Richfield Hanford Company are gratefully acknowledged. Particularly helpful to the study were the discussions and information supplied by R. E. Brown, F. P. Hungate, R. L. Junkins, C. L. Simpson, E. C. Watson, W. A. Haney, R. E. Isaacson, G. L. Ritter, and R. E. Tomlinson. 
BNWL- 1194

APPENDICES 
BNWL - 1194

\section{APPENDIX A}

\section{WIND EROSION CONSEQUENCES}

If part of a tank farm were uncovered by wind erosion, continuing erosion would slowly remove the material from the exposed salt cakes and disperse it in a downwind direction. The remains of the old containment tank itself might provide some containment and protection against this erosion. However, for predicting the worst possible situation, no protection by the tank is assumed.

The rate of weathering of the salt would be slow. For purposes of this calculation, the following are taken as typical of the worst conditions and erosion rates to be encountered:

- The equivalent of the entire top surface area of one salt cake is exposed to wind erosion by the removal of the overburden

- An erosion rate of 1 in. of salt cake per day occurs

- The erosion lasts one day prior to discovery and corrective action

- The ${ }^{137} \mathrm{Cs}$ is dispersed uniformly throughout the salt cake

- The ${ }^{90} \mathrm{Sr}$ is concentrated in the bottom layer of precipitated hydrous metal oxides in the salt cake. A maximum of $10 \%$ of the total tank inventory of ${ }^{90} \mathrm{Sr}$ is uniformly dispersed in the salt cake (40) $^{(4)}$

- The plutonium and americium radionuclides are concentrated in the bottom layer of precipitated hydrous metal oxides in the salt cake. A maximum of $10 \%$ of the total tank inventory of these radionuclides is uniformly dispersed in the salt cake(40)

- The exposed salt cake material contains the maximum radionuclide inventory as given in Table 1

- The salt cake measures $75 \mathrm{ft}$ in diameter and is $17.5 \mathrm{ft}$ in height (an assumed typical tank filling). 
The concentrations of ${ }^{137} \mathrm{Cs},{ }^{90} \mathrm{Sr},{ }^{239} \mathrm{Pu},{ }^{241} \mathrm{Pu}$, and ${ }^{241} \mathrm{Am}$ in the bulk salt cake, not including the sludge materials at the bottom of the salt cake, are shown in Table A-1.

\section{TABLE A-1. Radionuclide Concentrations}

\begin{tabular}{cc} 
Radionuclide & $\mathrm{Ci/ \textrm {cm } ^ { 3 }}$ \\
\hline${ }^{137} \mathrm{Cs}$ & $7 \times 10^{-4}$ \\
${ }^{90} \mathrm{Sr}$ & $7 \times 10^{-5}$ \\
$239 \mathrm{Pu}$ & $2 \times 10^{-8}$ \\
$241 \mathrm{Pu}$ & $3 \times 10^{-8}$ \\
$241 \mathrm{Am}$ & $2 \times 10^{-9}$
\end{tabular}

After about 100 years of decay, the ${ }^{241} \mathrm{Pu}$ inventory will have experienced some seven half-lives of decay and will be approaching zero, while the ${ }^{241} \mathrm{Am}$ inventory will be nearing its maximum of about $60 \mathrm{Ci}$. The concentration of ${ }^{241} \mathrm{Am}$ in the salt cake will then be $3 \times 10^{-9} \mathrm{Ci} / \mathrm{cm}^{3}$.

For the conditions assumed, the total number of cubic centimeters of salt cake eroded away is $1 \times 10^{7}$.

The total radionuclide inventory dispersed to the atmosphere per day from this event is given in Table A-2.

TABLE A-2. Radionuclides Dispersed

$$
\begin{array}{cc}
\text { Radionuclide } & \frac{\text { Total Ci/day }}{{ }^{137} \mathrm{Cs}} \\
{ }^{90} \mathrm{Sr} & 7 \times 10^{3} \\
{ }^{239} \mathrm{Pu} & 2 \times 10^{2} \\
241_{\mathrm{Pu}} & 3 \times 10^{-1} \\
241_{\mathrm{Am}} & 2 \times 10^{-1} \\
& 2 \times 10^{-2}
\end{array}
$$


For an erosion time of $24 \mathrm{hr}$, the average release rate in curies per second is given in Table A-3.

TABLE A-3. Radionuclide Release Rate

$\begin{array}{cc}\text { Radionuclide } & \begin{array}{c}\text { Release Rat } \\ \mathrm{Ci} / \mathrm{sec}\end{array} \\ & 8 \times 10^{-2} \\ 90_{\mathrm{Sr}} & 8 \times 10^{-3} \\ 239_{\mathrm{Pu}} & 2 \times 10^{-6} \\ 241_{\mathrm{Pu}} & 3 \times 10^{-6} \\ 241_{\mathrm{Am}} & 2 \times 10^{-7}\end{array}$

For this example, a $10 \mathrm{~m} / \mathrm{sec}$ wind speed under very stable atmospheric conditions was considered. For these conditions, the ground level air concentrations and the ground dispositions at various distances downwind were taken from the work of Watson using a deposition coefficient of $1.5 \times 10^{-4}$. (41) The ground level air concentrations are shown in Table A-4.

TABLE A-4. Ground Level Air Concentrations

Distance, In

$\mathrm{m}$
$10^{2}$
$10^{3}$
$10^{4}$
$10^{5}$
$10^{6}$

Average Ground Leve1 Air Concentrations over 24-hr Period, $\mu \mathrm{Ci} / \mathrm{cm} 3$

\begin{tabular}{|c|c|c|c|c|c|c|c|c|c|}
\hline & $137 \mathrm{Cs}$ & & $90 \mathrm{Sr}$ & & $239 \mathrm{Pu}$ & & $241_{\mathrm{Pu}}$ & & $241_{\mathrm{Am}}$ \\
\hline & $\times 10^{-4}$ & 3 & $\times 10^{-5}$ & 8 & $\times 10^{-9}$ & & $\times 10^{-8}$ & 8 & $\times 10^{-10}$ \\
\hline & $\times 10^{-5}$ & 1 & $\times 10^{-6}$ & 3 & $\times 10^{-10}$ & 5 & $\times 10^{-10}$ & 3 & $\times 10^{-11}$ \\
\hline & $\times 10^{-6}$ & 1 & $\times 10^{-7}$ & 3 & $\times 10^{-11}$ & 5 & $\times 10^{-11}$ & 3 & $\times 10^{-12}$ \\
\hline & $\times 10^{-8}$ & 4 & $\times 10^{-9}$ & 1 & $\times 10^{-12}$ & 2 & $\times 10^{-12}$ & 1 & $\times 10^{-13}$ \\
\hline & $\times 10^{-11}$ & 8 & $\times 10^{-12}$ & 2 & $\times 10^{-15}$ & 3 & $\times 10^{-15}$ & & $\times 10^{-16}$ \\
\hline
\end{tabular}

For a person exposed the entire 24 -hr period, the maximum possible quantity of radionuclides entering the body by inhalation can be calculated from the standard man breathing rate of $230 \mathrm{~cm}^{2} / \mathrm{sec}$ and from the air concentrations. For ${ }^{137} \mathrm{Cs}, 75 \%$ of the inhaled material is assumed to be deposited in the 
critical organ. For the ${ }^{90} \mathrm{Sr},{ }^{239} \mathrm{Pu},{ }^{241} \mathrm{Pu}$, and ${ }^{241} \mathrm{Am}, 25 \%$ of the inhaled quantity is assumed to reach the critical organ. For a distance of about 10 miles from an eroding salt cake, the depositions 1 isted in Table A-5 could be experienced.

\section{TABLE A-5. Radionuclide Deposition by Inhalation} (at 210 miles)

\begin{tabular}{|c|c|c|c|}
\hline Radionuclide & $\begin{array}{c}\text { Deposition, } \\
\mu \mathrm{Ci} \\
\end{array}$ & $\begin{array}{l}\text { Maximum Permissible } \\
\text { Body Burden }(42), \mu C i\end{array}$ & $\begin{array}{l}\text { Critical } \\
\text { Body } \\
\end{array}$ \\
\hline${ }^{137} \mathrm{Cs}$ & $2 \times 10^{1}$ & $3 \times 10^{1}$ & $\begin{array}{l}\text { Total } \\
\text { Body }\end{array}$ \\
\hline${ }^{90} \mathrm{Sr}$ & $5 \times 10^{-1}$ & 2 & Bone \\
\hline${ }^{239} \mathrm{Pu}$ & $2 \times 10^{-4}$ & $4 \times 10^{-2}$ & Bone \\
\hline $241_{\mathrm{Pu}}$ & $3 \times 10^{-4}$ & $9 \times 10^{-1}$ & Bone \\
\hline $241_{\mathrm{Am}}$ & $2 \times 10^{-5}$ & $5 \times 10^{-2}$ & Bone \\
\hline
\end{tabular}

The exposures for each radionuclide would be less than the most restrictive maximum permissible body burden recommended by the National Council on Radiation Protection and Measurement for radiation workers.

The ground deposition activity levels of these radionuclides in $\mu \mathrm{Ci} / \mathrm{m}^{2}$ resulting from this exposure was calculated by the methods given by Watson (41) and are 1 isted in Table A- 6 .

\section{TABLE A-6. Ground Deposition Activity Levels}

\begin{tabular}{|c|c|c|c|c|c|c|c|c|c|c|c|}
\hline \multirow{3}{*}{$\begin{array}{c}\text { Distance, } \\
\frac{\mathrm{m}}{10^{2}}\end{array}$} & \multicolumn{11}{|c|}{ Ground Deposition, $\mu \mathrm{Ci} / \mathrm{m}^{2}$} \\
\hline & \multicolumn{2}{|c|}{$137 \mathrm{Cs}$} & \multicolumn{2}{|r|}{$90 \mathrm{Sr}$} & \multicolumn{2}{|c|}{$239 \mathrm{Pu}$} & \multicolumn{3}{|c|}{$241_{\mathrm{Pu}}$} & \multicolumn{2}{|c|}{$241_{\mathrm{Am}}$} \\
\hline & & $\times 10^{4}$ & 4 & $\times 10^{3}$ & 1 & & 1 & & & 1 & $10^{-1}$ \\
\hline $10^{3}$ & 1 & $\times 10^{3}$ & 1 & $\times 10^{2}$ & $4 \times$ & $10^{-2}$ & 7 & $x$ & $10^{-2}$ & 4 & $10^{-3}$ \\
\hline $10^{4}$ & 1 & $\times 10^{2}$ & 1 & 10 & $4 \times$ & $10^{-3}$ & 7 & $x$ & $10^{-3}$ & $4 \times$ & $10^{-4}$ \\
\hline $10^{5}$ & 5 & & 5 & $\times 10^{-1}$ & $1 \times$ & $10^{-4}$ & 3 & $x$ & $10^{-4}$ & 1 & $10^{-5}$ \\
\hline $10^{6}$ & 1 & $\times 10^{-2}$ & 1 & $\times 10^{-3}$ & $3 \times$ & $10^{-7}$ & 4 & $x$ & $10^{-7}$ & $3 \times$ & $10^{-8}$ \\
\hline
\end{tabular}


There are a series of actions that are appropriate for various levels of ground depositions of these radionuclides. For purposes of estimating the consequences of this postulated event, the activity level at which various possible actions would be taken are summarized in Table $A-7$.

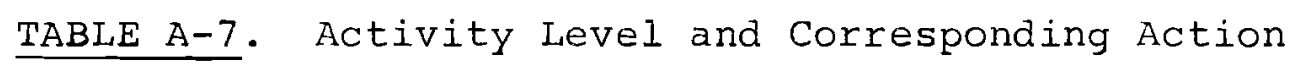

\begin{tabular}{|c|c|c|}
\hline Radionuclide & $\begin{array}{c}\text { Activity Leve1, } \\
\mu \mathrm{Ci} / \mathrm{m} 2\end{array}$ & Possible Action \\
\hline \multirow[t]{3}{*}{$137 \mathrm{Cs}$} & 2000 & Evacuate people \\
\hline & 50 & $\begin{array}{l}\text { Confiscate crops } \\
\text { for several years }\end{array}$ \\
\hline & 10 & $\begin{array}{l}\text { Confiscate crops } \\
\text { for one year }\end{array}$ \\
\hline \multirow[t]{3}{*}{${ }^{90} \mathrm{Sr}$} & 20 & Evacuate people \\
\hline & 3 & $\begin{array}{l}\text { Confiscate crops } \\
\text { for several years }\end{array}$ \\
\hline & 0.1 & $\begin{array}{l}\text { Confiscate crops } \\
\text { for one year }\end{array}$ \\
\hline $239 \mathrm{Pu}$ & 0.1 & Evacuate people \\
\hline${ }^{241_{\mathrm{Pu}}}$ & 2 & Evacuate people \\
\hline $241_{\mathrm{Am}}$ & 0.1 & Evacuate people \\
\hline
\end{tabular}

The activity levels for ${ }^{239} \mathrm{pu}, 241_{\mathrm{Pu}}$, and ${ }^{241_{\mathrm{Am}}}$ requiring confiscation of crops for one or more years are about equal to, or greater than, those at which personnel evacuation would be required. If it is safe for people to live in the area contaminated with these radionuclides, then it will be safe to raise crops.

The control activity levels for ${ }^{137} \mathrm{Cs}$ were established by calculating the quantity of ${ }^{137} \mathrm{Cs}$ uptake in the body from various path ways. The total body dose equivalent is limited to 0.3 rem per year by use of these controls. The dose equivalent to the bone from eating crops or inhalation of resuspensed 
radioactive material in a contaminated area will be limited to $0.3 \mathrm{rem}$ per year by using these controls for the radionuclides of ${ }^{90} \mathrm{Sr},{ }^{239} \mathrm{Pu},{ }^{241} \mathrm{Pu}$, and ${ }^{241} \mathrm{Am}$.

The activity levels and their corresponding possible action levels given in Table A-7 were found to be comparable with those established by Guthrie and Nichols of Oak Ridge National Laboratory. (43) The single value activity level given here is usually bracketed by the range of values given by Guthrie and Nichols. In the case of temporary evacuation of people, the values used in this study exceed those used by Guthrie and Nichols by a factor of 4 and 2 for ${ }^{137} \mathrm{Cs}$ and ${ }^{90} \mathrm{Sr}$, respectively. For purposes of estimating the consequences of accidents, the differences in the criteria are not significant. In the event of an accident, the appropriate protective actions, based on measurement and other related information, would be decided by authorities.

For this postulated event, the distance requiring controlled use of land 1isted in Table A-8 would be appropriate at the listed distances downwind from the uncovered salt cake.

TABLE A-8. Distance Requiring Controlled Use of Land

\begin{tabular}{|c|c|c|c|}
\hline $\begin{array}{l}\text { Radionuclide } \\
\text { Causing } \\
\text { Action } \\
\end{array}$ & $\begin{array}{l}\text { Evacuate } \\
\text { Peop1e }\end{array}$ & $\begin{array}{l}\text { Confiscate Crops } \\
\text { for Several years }\end{array}$ & $\begin{array}{l}\text { Confiscate Crops } \\
\text { for One Year }\end{array}$ \\
\hline${ }^{137} \mathrm{Cs}$ & 0.3 & (2) & - \\
\hline${ }^{90} \mathrm{Sr}$ & 3 & 15 & 100 \\
\hline${ }^{239} \mathrm{Pu}$ & 0.3 & - & - \\
\hline${ }^{241} \mathrm{Pu}$ & 0.1 & - - & - \\
\hline $241_{\mathrm{Am}}$ & 0.3 & $\cdots$ & -- \\
\hline
\end{tabular}

The external exposure rate received while in the airborne cloud of ${ }^{137} \mathrm{Cs}$ is shown in Table A-9. 
TABLE A-9. External Exposure Rate from Airborne Cloud of $137 \mathrm{Cs}$

\begin{tabular}{c}
$\begin{array}{c}\text { Distance From } \\
\text { Source, m }\end{array}$ \\
\hline $10^{3}$ \\
$10^{4}$ \\
$10^{5}$ \\
$10^{6}$
\end{tabular}

\begin{tabular}{c} 
Air Concentration, \\
$\mu \mathrm{Ci} / \mathrm{cm}^{3}$ \\
\hline $1 \times 10^{-5}$ \\
$1 \times 10^{-6}$ \\
$4 \times 10^{-8}$ \\
$8 \times 10^{-11}$
\end{tabular}

\begin{tabular}{c}
$\begin{array}{c}\text { Dose Rate, } \\
\mathrm{mR} / \mathrm{hr}\end{array}$ \\
\hline $1 \times 10^{-1}$ \\
$1 \times 10^{-2}$ \\
$6 \times 10^{-4}$ \\
$1 \times 10^{-6}$
\end{tabular}

The resulting external exposure rate from airborne ${ }^{137} \mathrm{Cs}$ for this event has a maximum value of $0.1 \mathrm{mR} / \mathrm{hr}$ at $1000 \mathrm{~m}$ from the salt cake.

The exposure rate from ${ }^{137} \mathrm{Cs}$ deposited on the ground is given in Table A-10. For construction of this table, a factor of $11 \mathrm{R} / \mathrm{hr}$ per $\mathrm{Ci} / \mathrm{m}^{2}$ was used to relate ground activity level to exposure rate. The exposure rate given is for a location $3 \mathrm{ft}$ above a flat plane surface.

TABLE A-10. Exposure Rate From Ground Deposited ${ }^{137} \mathrm{Cs}$

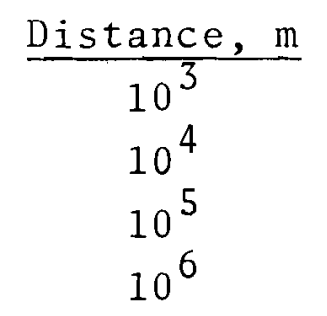

Exposure Rate, $\mathrm{mR} / \mathrm{hr}$

10

1

0.06

0.0001 


\section{APPENDIX B}

\section{NUCLEAR WEAPON CONSEQUENCES}

The ${ }^{137} \mathrm{Cs}$ and ${ }^{90} \mathrm{Sr}$ yield of a nuclear weapon may be calculated from the total fission yield values of $6.6 \%$ for ${ }^{137} \mathrm{Cs}$ and $2.2 \%$ for ${ }^{90} \mathrm{Sr} .(44,45)$ These yield values are for ${ }^{239} \mathrm{Pu}$ fissions produced by ${ }^{239} \mathrm{Pu}$ fission spectrum energy neutrons. The calculations show that, for each kiloton (kT) of weapon power, about $200 \mathrm{Ci}$ of ${ }^{137} \mathrm{Cs}$ and about $60 \mathrm{Ci}$ of ${ }^{90} \mathrm{Sr}$ are produced in addition to a multitude of shorter half-life materials. For surface burst, about one-half of the fission products remain suspended in the atmosphere long enough to appear as delayed fallout. For these conditions, the quantities of ${ }^{137} \mathrm{Cs},{ }^{90} \mathrm{Sr}$, and ${ }^{239} \mathrm{Pu}$ available for early fallout for two weapon sizes are summarized in Table B-1.

TABLE B-1. Radionuclide Inventory in Curies for Early Fallout

\begin{tabular}{|c|c|c|c|c|c|c|}
\hline \multirow[b]{2}{*}{ Radionuclide } & \multicolumn{2}{|c|}{$\begin{array}{l}\text { Generated By } \\
\text { Weapons, }\end{array}$} & \multirow{2}{*}{$\begin{array}{l}\text { From } \\
\text { Farm }\end{array}$} & \multirow{2}{*}{$\begin{array}{l}\text { Tank } \\
\text { Waste } \\
\end{array}$} & \multicolumn{2}{|c|}{$\begin{array}{c}\text { Total in Early } \\
\text { Fallout }\end{array}$} \\
\hline & $300 \mathrm{kT}$ & $3 \mathrm{MT}$ & & & $300 \mathrm{kT}$ & $3 \mathrm{MT}$ \\
\hline${ }^{137} \mathrm{Cs}$ & $3 \times 10^{4}$ & $3 \times 10^{5}$ & $1 \times$ & $10^{7}$. & $1 \times 10^{7}$ & $1 \times 10^{7}$ \\
\hline${ }^{90} \mathrm{Sr}$ & $2 \times 10^{4}$ & $2 \times 10^{5}$ & $1 \times$ & $10^{7}$ & $1 \times 10^{7}$ & $1 \times 10^{7}$ \\
\hline${ }^{239} \mathrm{Pu}$ & - - & - - & $7 \times$ & $10^{3}$ & $7 \times 10^{3}$ & $7 \times 10^{3}$ \\
\hline${ }^{241} \mathrm{Pu}$ & - & - - & $1 \times$ & $10^{4}$ & $1 \times 10^{4}$ & $1 \times 10^{4}$ \\
\hline${ }^{241} \mathrm{Am}$ & & & $7 \times$ & $10^{2}$ & $7 \times 10^{2}$ & $7 \times 10^{2}$ \\
\hline
\end{tabular}

This presentation is limited to considerations of the contributions of radionuclide waste storage inventory to a nuclear detonation event. The contributions arising from the multitude of fission fragments created are considered only with respect to their contributions to the predicted external exposure rates. Control actions for people and crops due to short halflife radioiodine and similar radionuclides produced by the 
detonation would be typical of the control actions required for a nuclear weapon detonation at any location and are not unique to a detonation at a waste storage area.

For the tank farm inventories considered here, the ${ }^{137} \mathrm{Cs}$ and ${ }^{90} \mathrm{Sr}$ produced by a $300 \mathrm{kT}$ weapon are only about $1 \%$ of the total quantities dispersed. For the 3 MT weapon, the weapon accounts for about $10 \%$ of the total quantity of ${ }^{137} \mathrm{Cs}$ and ${ }^{90} \mathrm{Sr}$ dispersed. The weapons contributions of ${ }^{239} \mathrm{Pu},{ }^{241} \mathrm{Pu}$, and 241 Am have been neglected in this presentation.

Based on the fallout patterns calculated by the AEC Weapons System Evaluation Group and summarized by the Savannah River Plant, (46) the downwind distance and the total area covered by concentration contours of interest for various wind speed were calculated. The resulting concentration areas were then compared to a set of activity level action guides to determine the areas for which controlled use of the land would be required.

Table A-7 gave the actions required at various radionuclide activity levels for peace time conditions. In a time of war, one can reasonably assume that this activity level would be raised by several orders of magnitude before the indicated action would be taken. For this analysis, a factor of 100 increase over normal limits was used to define the activity level probably requiring controlled use of the land. Table B-2 gives the activity level and possible action relationships used in the following analysis. 
TABLE B-2. Assumed Activity Level and Corresponding Possible Actions Under War Time Conditions

\begin{tabular}{|c|c|c|}
\hline Radionuclide & Activity Level, $\mu \mathrm{Ci} / \mathrm{m}^{2}$ & Possible Action \\
\hline \multirow[t]{3}{*}{$137 \mathrm{Cs}$} & 200,000 & Evacuate people \\
\hline & 5,000 & $\begin{array}{l}\text { Confiscate crops } \\
\text { for several years }\end{array}$ \\
\hline & 1,000 & $\begin{array}{l}\text { Confiscate crops } \\
\text { for one year }\end{array}$ \\
\hline \multirow[t]{3}{*}{${ }^{90} \mathrm{Sr}$} & 2,000 & Evacuate people \\
\hline & 300 & $\begin{array}{l}\text { Confiscate crops } \\
\text { for several years }\end{array}$ \\
\hline & 10 & $\begin{array}{l}\text { Confiscate crops } \\
\text { for one year }\end{array}$ \\
\hline $239 \mathrm{Pu}$ & 10 & Evacuate people \\
\hline $241_{\mathrm{Pu}}(\mathrm{a})$ & 100 & Evacuate people \\
\hline $241_{A m}(a)$ & 10 & Evacuate people \\
\hline
\end{tabular}

(a) Estimated by comparing most restrictive maximum permissible body burdens with corresponding values for $239 \mathrm{Pu}$.

Table B-3 gives the distances and the total areas that could be subject to the stated actions for ${ }^{137} \mathrm{Cs}$ for a $300 \mathrm{kT}$ weapon.

TABLE B-3. $\quad{ }^{137} \mathrm{Cs}$ Control Action Contours, $300 \mathrm{kT}$ Weapon

\begin{tabular}{|c|c|c|c|c|}
\hline Contour,$\mu \mathrm{Ci} / \mathrm{m}^{2}$ & $\begin{array}{c}\text { Distance, } \\
\text { miles } \\
\end{array}$ & $\begin{array}{l}\text { Area, } \\
\text { miles } \\
\end{array}$ & $\begin{array}{c}\text { Distance, } \\
\text { miles } \\
\end{array}$ & $\begin{array}{l}\text { Area, } \\
\text { miles } 2 \\
\end{array}$ \\
\hline $\begin{array}{l}200,000 \\
\text { (Evacuate people) }\end{array}$ & $<10$ & $<10$ & $<10$ & $<10$ \\
\hline $\begin{array}{l}5000 \\
\text { (Confiscate crops } \\
\text { several years) }\end{array}$ & $<10$ & $<10$ & $<10$ & $<10$ \\
\hline $\begin{array}{l}1000 \\
\text { (Confiscate crops } \\
\text { one year) }\end{array}$ & $<10$ & $<10$ & $<10$ & $<10$ \\
\hline
\end{tabular}

Distance and Area of Possible Action Wind Speed

$\frac{5 \mathrm{~m} / \mathrm{sec}}{\overline{\text { Distance, Area, }}} \frac{10 \mathrm{~m} / \mathrm{sec}}{\text { Distance, Area, }}$


No areas beyond 10 miles from the tank farm are contaminated to activity levels requiring control actions due to the presence of ${ }^{137} \mathrm{Cs}$.

For ${ }^{90} \mathrm{Sr}$, Table B-4 gives the distances and the total areas that could be subject to the actions stated.

TABLE B-4. ${ }^{90} \mathrm{Sr}$ Control Action Contours, $300 \mathrm{kT}$ Weapon

\begin{tabular}{|c|c|c|c|c|}
\hline \multirow[b]{3}{*}{ Contour, $\mu \mathrm{Ci} / \mathrm{m}^{2}$} & \multirow{2}{*}{\multicolumn{2}{|c|}{$\begin{array}{c}\text { Distance and Area } \\
\text { Wind }\end{array}$}} & \multicolumn{2}{|c|}{$\begin{array}{l}\text { of Possible Action } \\
\text { Speed }\end{array}$} \\
\hline & & & $10 \mathrm{~m}$ & \\
\hline & $\begin{array}{c}\text { Distance, } \\
\text { miles }\end{array}$ & $\begin{array}{l}\text { Area, } \\
\text { miles }\end{array}$ & $\begin{array}{c}\begin{array}{c}\text { Distance, } \\
\text { miles }\end{array} \\
\end{array}$ & $\begin{array}{l}\text { Area, } \\
\text { miles } \\
\end{array}$ \\
\hline $\begin{array}{l}2000 \\
\text { (Evacuate people) }\end{array}$ & $<10$ & $<10$ & $<10$ & $<10$ \\
\hline $\begin{array}{l}300 \\
\text { (Confiscate crops } \\
\text { several years) }\end{array}$ & 40 & 300 & 30 & 400 \\
\hline $\begin{array}{l}10 \\
\text { (Confiscate crops } \\
\text { one year) }\end{array}$ & 160 & 10,000 & 260 & 15,000 \\
\hline
\end{tabular}

For ${ }^{239} \mathrm{Pu}$ and ${ }^{241} \mathrm{Am}$ dispersed from the tank farm by a $300 \mathrm{kT}$ weapon, the distance and area contaminated to greater than $10 \mu \mathrm{Ci} / \mathrm{m}^{2}$ would be less than $10 \mathrm{miles}$ and less than 10 square miles, respectively. Similarly, ${ }^{241} \mathrm{Pu}$ ground activity levels exceeding $100 \mu \mathrm{Ci} / \mathrm{m}^{2}$ would not occur at distances exceeding 10 miles, or for areas exceeding 10 square miles

A larger weapon is more likely to be typical of one that an enemy would use. A 3 MT weapon will be considered. The total radionuclide inventory available for early fallout was taken as that given in Table B-1. Although the inventory is the same as that considered for the $300 \mathrm{kT}$ weapon, the distances and areas of control are somewhat different due to the increased size of the weapon. The $3 \mathrm{MT}$ weapon would create a crater about $400 \mathrm{ft}$ in depth and $1500 \mathrm{ft}$ in diameter. Table B-5 gives the distances and the total areas that could be subject to the action stated. 
BNWL - 1194

TABLE B-5. ${ }^{137} \mathrm{Cs}$ Control Action Contours, 3 MT Weapon

$\frac{\text { Contour, } \mu \mathrm{Ci} / \mathrm{m}^{2}}{200,000}$

5000

(Confiscate crops

severa1 years)

1000

(Confiscate crops

one year)
Distance and Area of Possible Action Wind Speed

\begin{tabular}{cccc}
\hline \multicolumn{2}{c}{$\mathrm{m} / \mathrm{sec}$} & \multicolumn{2}{c}{$10 \mathrm{~m} / \mathrm{sec}$} \\
\hline $\begin{array}{c}\text { Distance, } \\
\text { miles }\end{array}$ & $\begin{array}{c}\text { Area, } \\
\text { miles }\end{array}$ & $\begin{array}{c}\text { Distance, } \\
\text { miles }\end{array}$ & $\begin{array}{c}\text { Area } \\
\text { miles } 2\end{array}$ \\
\hline$<10$ & $\frac{<10}{<10}$ & $<10$ & $<10$
\end{tabular}

$<10<10 \quad<10 \quad<10$

$<10 \quad<10 \quad<10<<10$

For this weapon also, no areas beyond 10 miles from the tank farm are contaminated to activity levels requiring control action due to the presence of ${ }^{137} \mathrm{Cs}$.

For ${ }^{90} \mathrm{Sr}$, Table B- 6 gives the distances and the total areas that could be subject to the action stated.

TABLE B-6. ${ }^{90}$ Sr Control Action Contours, 3 MT Weapon

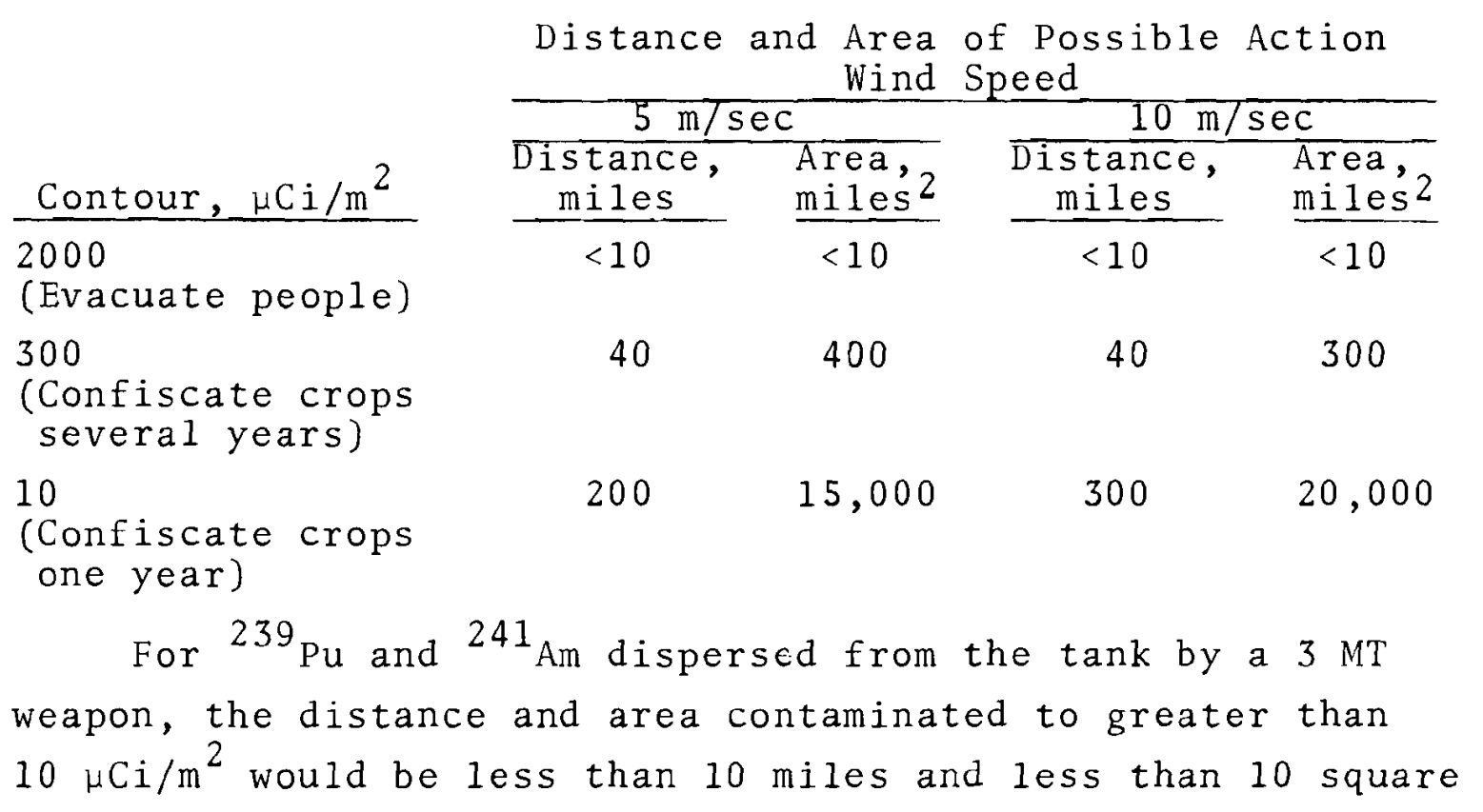


miles, respectively. Similar $1 y,{ }^{241} \mathrm{Pu}$ ground activity levels exceeding $100 \mu \mathrm{Ci} / \mathrm{m}^{2}$ would not occur at distances exceeding 10 miles, or for areas exceeding 10 square miles.

Although the size of the weapon will determine the initial exposure rate values at various distances from the tank farm, the weapon contributions to the exposure rate decay rapidly. After a few months, the weapon contributions will decrease due to radioactive decay alone by a factor of 10,000 , while the ${ }^{137} \mathrm{Cs}$ contributions from the tank farm have not decreased significantly. (47) For a location where the exposure rate at $1 \mathrm{hr}$ after the weapon burst was $10 \mathrm{R} / \mathrm{hr}$, the exposure rate at 60 days will be about $1 \mathrm{mR} / \mathrm{hr}$ from weapon fallout. For this short time period, the ${ }^{137} \mathrm{Cs}$ contributions to the exposure rate would not change significantly.

For a downwind location some 200 miles from the tank farm, an exposure rate of $3 \mathrm{R} / \mathrm{hr}$ may be expected at $12 \mathrm{hr}$ after a $3 \mathrm{MT}$ weapon burst for a wind speed of $15 \mathrm{mph}$. The total ${ }^{137} \mathrm{Cs}$ deposition at this location could be about $20 \mu \mathrm{Ci} / \mathrm{m}^{2}$. For ${ }^{137} \mathrm{Cs}$, an exposure rate of $11 \mathrm{R} / \mathrm{hr}$ per $\mathrm{Ci} / \mathrm{m}^{2}$ results at a height of $3 \mathrm{ft}$ above the ground. Hence, for this location, the exposure rate due to the ${ }^{137} \mathrm{Cs}$ from the tank farm will be $0.2 \mathrm{mR} / \mathrm{hr}$. The different rates of decay for the weapon fallout material and for the ${ }^{137} \mathrm{Cs}$ result in the exposure rate-time relationships shown in Table B-7 for a downwind location 200 miles from the tank farm. The rates of decay would, of course, be the same for any other location. However, the absolute magnitude of the exposure rate would be different. 
BNWL- 1194

TABLE B-7. Dose Rate-Time Relationships

\begin{tabular}{|c|c|c|c|}
\hline Time & $\begin{array}{l}\text { Dose Rate Due } \\
\text { To Weapon } \\
\text { Fallout, } \\
\text { mR/hr } \\
\end{array}$ & $\begin{array}{c}\text { Dose Rate Due } \\
\text { To Tank Farm } \\
\text { 137Cs Fallout, } \\
\text { mR/hr } \\
\end{array}$ & $\begin{array}{l}\text { Ratio: } \\
\left(\frac{\text { Weapons Fallout }}{\text { I37Cs Fallout }}\right)\end{array}$ \\
\hline $12 \mathrm{hr}$ & 3000 & 0.2 & 15,000 \\
\hline $24 \mathrm{hr}$ & 60 & 0.2 & 300 \\
\hline 1 wk & 6 & 0.2 & 30 \\
\hline $1 \mathrm{mo}$ & 1 & 0.2 & 5 \\
\hline 4 mo & 0.2 & 0.2 & 1 \\
\hline $1 \mathrm{yr}$ & 0.02 & 0.2 & 0.1 \\
\hline $2 \mathrm{yr}$ & 0.0005 & 0.2 & 0.0025 \\
\hline $5 \mathrm{yr}$ & 0.0000002 & 0.2 & 0.000001 \\
\hline $30 \mathrm{yr}$ & - - & 0.1 & - - \\
\hline
\end{tabular}

At about four months, the fallout exposure rate from the weapon just equals the ${ }^{137} \mathrm{Cs}$ fallout exposure rate of $0.2 \mathrm{mR} / \mathrm{hr}$. By the end of one year, the weapon fallout exposure rate at this selected downwind location is only onetenth of the ${ }^{137} \mathrm{Cs}$ exposure rate and is less than twice the natural background. 
BNWL - 1194

\section{APPENDIX C}

\section{REFERENCES}

1. P. W. Smith and R. E. Tomlinson. Hanford High Level Waste Management Reevaluation Study, ISO-981 AtZantic Richfield Hanford Company, Richland, Washington, August 31, 1967.

2. P. Hatch, J. B. Kendall, B. J. McMurray, and L. W. Roddy. Chemical Processing Division Hazards Evaluation TK 108-SX Stabilization Prototype, ISO-937. Atiantic Richfield Hanford Company, Richland, Washington, June 27, 1967.

3. J. J. Shefcik. First In-Tank Waste Solidification Unit Information Manual, HW-83218. Available from Clearinghouse for Federal Scientific and Technical Information, Springfield, Virginia, August 1, 1964.

4. G. E. Backman, E. M. Johnston, H. C. Rathvon, L. W. Roddy, and M. F. Wiitala. Chemical Processing Department Hazards Evaluation In-Tank waste Solidification Project CAC-965, RL-SEP-65. Available from Clearinghouse for Federal Scientific and Technical Information, Springfield, Virginia, November 24, 1964 .

5. L. W. Godfrey. Unpublished Data. AtZantic Richfield Hanford Company, Richland, Washington, July 1969. (Personal Communication)

6. P. W. Smith. Unpublished Data. Atlantic Richfield Hanford Company, Richland, Washington, October 1967. (Personal Communication)

7. J. F. Phizlips. Unpublished Data. Battelze-Northwest, Richland, Washington, February 1967. (Personal Communication)

8. C. L. Brown. Unpublished Data. Battelle-Northwest, Richland, Washington, August 1969. (Personal Communication)

9. R. E. Brown. A Study of Reported Faulting in the Pasco Basin, BNWL-662. Battelie-Northwest, Richland, Washington, January 9, 1968.

10. R. E. Brown and D. J. Brown. The Geology of the Pasco Basin, BNWL-947. Battelle-Northwest, Richland, Washington (to be published)

11. D. J. Brown. Unpublished Data. Battelie-Northwest, Richzand, Washington, October 196?. (Personal

Communication) 
BNWL - 1194

12. L. Gemme22. "Discussion of Brookhaven Waste Disposal Experience," Second Ground Disposal of Radioactive Wastes Conference (held at Chalk River, Canada), TID-7628, pp.559-564. AEC Division of Technical Information Extension, Oak Ridge, Tennessee, September 26-29, 1961.

13. D. E. Jenne and R. E. Kerns. A Climatological Study of the Hanford Area, HW-57722. Avaizable from Clearinghouse for Federal Scientific and Technical Information, Springfield, Virginia, November 1959.

14. C. L. Simpson. Unpublished Data. Battelle-Northwest, Richland, Washington, October 1969. (Personal Communication)

15. W. A. Haney and J. F. Honstead. A History and Discussion of Specific Retention Disposal of Radioactive Liquid Wastes in the 200 Areas, HW-54599. Available from clearinghouse for Federal Scientific and Technical Information, Springfiezd, Virginia, January 1958.

16. W. H. Biershank. Techniques for Estimating Specific Retention Properties of Hanford Soils, HW-61644, Rev. Available from Clearinghouse for Federal scientific and Technical Information, Springfield, Virginia, August 20,1959 .

17. B. F. Hajek. Unpublished Data. Battelle-Northwest Richland, Washington, November 1966. (Preliminary Report: Plutonium and Americium Mobizity in Soizs) BNWL-CC-925.

18. B. F. Hajek. Unpublished Data. Battelle-Northwest, Richland, Washington, July 1965. (Preliminary Report: Adsorption, Migration, and Dispersion of Strontium and Cesium in an $N$-Area SoiZ)

19. B. F. Hajek and K. C. Knolz. Unpublished Data. BattelzeNorthwest, Richland, Washington, June $70,1966$.

(Preliminary Report: Disposal Characteristics of Plutonium and Americium in High Salt Acid Waste)

20. D. W. Rhodes. The Adsorption of Plutonium by Soiz. General Electric Company, Richland, Washington.

21. D. J. Brown and W. A. Haney. Chemical Effluents Technology Waste Disposal Investigations July - December, 1963 The Movement of Contaminated Ground Water from the 200 Areas to the Columbia River, HW-80909. February 18, 1964.

22. D. J. Brown. Unpublished Data. Battelle-Northwest, Richland, Washington, october 1967. (Personal Communication)

23. F. O. Jones and $R$. J. Deacon. Unpublished data on the geology and tectonic history of the Hanford area. June 15, 1966. 
24. J. R. Raymona and D. D. Tizlson. Evaluation of a Thick Basalt Sequence in South Central Washington, BNWL-776. Battelle-Northwest, Richland, Washington, Apriz 1968.

25. R. H. Jahns. Geologic Factors Relating to Engineering Seismology in the Hanford Area, Washington, DUN-3100. Douglas United Nuclear, Pichiand, Washington, october 1967.

26. G. W. Housner. Recommended Seismic Design Criteria for Hanford Nuclear Facility, DUN-3130. Douglas United Nuclear, Richland, Washington, october 1967.

27. R. E. Brown and $T$. R. Raymond. Geophysical Seismic Evaluation Study at Hanford, BNWL-47, Battelie-Northwest, Richland, lashington, December 1964.

28. D. J. Brown. Subsurface Geology of the Hanford Separation Areas, Hw-61780. Available from Clearinghouse for Federal Scientific and Technical Information, Springfield, Virginia, october 1967.

29. J. R. Raymond. Unpublished Data. Battelle-Northwest, Richland, Washington, September 10, 1968. (Letter Report: Seismic Monitoring - Gable Mountain Quarry Blast)

30. N. H. Rasmussen. Unpublished Data. Douglas United Nuclear, Richland, Washington, May 1966. (Seismology Report on Washington, Idaho, Northern Oregon and Western Montana and the Hanford Area)

31. F. Neumann. Unpublished Data. University of Washington, Seattie, Washington, November 1959. (Report to General Electric Compary, Richland, Washington: Seismological Investigations at the Hanford Works)

32. N. F. Fifer. 1918 Corfu Earthquake, DUN-1524. Douglas United Nuclear, Richland, Washington, September 1966.

33. G. W. Housner. Unpublished Data. Douglas United Nuclear, Richland, Washington, May 1968. (Letter Report: Probability of Earthquake Ground Shaking in Southeastern Washinaton 1

34. R. H. Jahns. Unpublished Data. August 6, 1967. (PreIiminary Report: Geologic Factors Relating to Engineering Seismology in the Hanford Area)

35. G. W. Housner. Unpublished Data. Pasadena, California, September 8, 1967. (Personal Communication to R. S. Peterson, Douglas United Nuclear, Richland, Washington: Recommended Seismic Design Criteria for Hanford Nuclear Facizity)

36. The Effects of Ben Franklin Dam on Hanford, edited by W. A. Haney, BNWL-412. Battelie-Northwest, Richland, Washington, May 1967. 
37. T. M. Beetze. Unpublished Data. BattelZe-Northwest, Richland, Washington, October 1967. (Personal Communication)

38. F. P. Hungate. Unpublished Data. Battelle-Northwest, Richland, Washington, october 1967. (Personal Communication)

39. W. C. Hanson. Unpublished Data. Battelze-Northwest, Richzand, Washington, October 1967. (Personal Communication)

40. R. E. Tomzinson. Unpublished Data. Atlantic Richfield Hanford Company, Richland, Washington, October 1967. (Personal Communication)

41. E. C. Watson and C. C. Gamertsfelder. Environmental Radioactive Contamination as a Factor in Nuclear Plant siting Criteria, HW-SA-2809. Available from Clearinghouse for Federal Scientific and Technical Information, Springfield Virginia, February 14, 1963.

42. National Counciz on Radiation Protection and Measurements. Maximum Permissible Body Burdens and Maximum Permissible Concentration of Radionuclides in $A$ ir and in water for occupational Exposure, Superintendent of Documents, Washington, D. C., June 5, 1959. Handbook 69.

43. C. E. Guthrie and J. P. Nichols. Theoretical Possibilities and Consequences of Major Accidents in U-233 and Pu-239 Fuel Fabrication and Radioisotope processing Flants, ORNL-3441. Oak Fidge National Laboratory, oak Ridge, Tennessee, April 1964.

44. J. A. Petruska, H. G. Thode, and R. H. Tomlinson. Canadian Journal of Physics, vol. 33, p. 693. 1955.

45. L. E. Glendenin, C. D. Coryezz, and R. R. Edwards. Radiochemical Studies: The Fission Products, National Nuclear Energy, Series IV-9. McGrow-Hizl Book Co., New York, 1951.

46. Vic Thayer. Dispersal of Radioactive Waste by Nuclear Bombing, DPW-63-150, REVI. E. I. du Font de Nemours, Wilmington, Delaware, September $26,1963$.

47. U.S. Department of Defense. The Effects of Nuclear Weapons. U.S. Atomic Energy Commission, Revised Edition. February 1964 . 


\section{DISTRIBLTION}

No. of

Copies

OFFSITE

1

AEC Chicago Patent Group

G. H. Lee

267

$\frac{\text { AEC Division of Technical Information Extension }}{\text { For UC-41 }}$

ONSITE-HANFORD

1

AEC Cricago Patent Group

R. K. Sharp (Richland)

2

AEC RDT Site Representative

P. C. Holsted

12 AEC Rich 1and Operations Office

A. Brunstad (6)

O. J. Elgert

E. H. Hess

E. E. Jackson (3)

C. L. Robinson

52 Atlantic Richfield Hanford Company

C. E. Backman

D. J. Brown

V. R. Chapmar

R. P. Corlew

D. E. Eliason

J. B. Fecht

W. M. Harty

R. E. Isaacson

L. M. Knights

G. C. Oberg

L. M. Richards

G. L. Ritter (25)

H. F. Shaw

P. W. Smith

R. E. Smith

R. E. Tomlinson (10)

$\mathrm{J}$. H. Warren

ARHCO Files (2) 
No. of Copies

Copies

Battelle Memorial Institute

$57 \quad$ Battelle-Northwest
E. L. Alpen
R. E. Burns
C. R. Cooley
D. R. deHalas
R. F. Foster
J. J. Fuquay
W. A. Haney
J. F. Honstead
R. T. Jaske
R. L. Junkins
G. E. King (10)
H. N. Parker
A. M. Platt
C. L. Simpson
C. J. Touhill
C. M. Unruh (25)
E. C. Watson
Technical Information (5)
Technical Publications (2) 